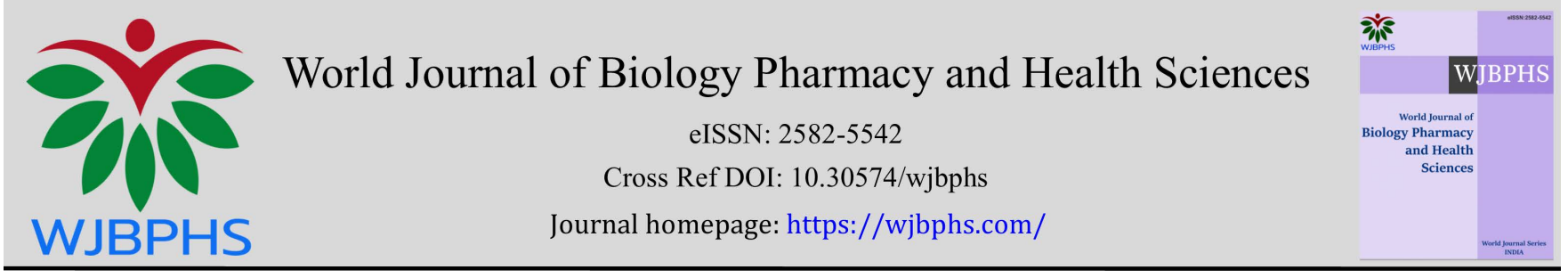

(REVIEW ARTICLE)

\title{
Ethnobotanical plants and their tradomedicinal values: A review
}

\author{
Olugbenga Kayode Popoola ${ }^{1,}{ }^{*}$, Kayode Damilola Adekeye ${ }^{1}$, Eunice Damilola Akinbinu ${ }^{2}$ Lanre Tope \\ Adekeye ${ }^{3}$, Michael Bolaji Afolayan ${ }^{1}$, Emmanuel Ayomide Bakare ${ }^{1}$ and Oluwatobi Emmanuel Akande 1 \\ ${ }^{1}$ Department of Chemistry, Faculty of Science, Ekiti State University, Ado-Ekiti, Nigeria \\ ${ }^{2}$ Department of Plant Science and Biotechnology, Faculty of Science, Ekiti State University, Ado-Ekiti, Nigeria \\ ${ }^{3}$ Department of Nursing, Faculty of Nursing, Medical University Ondo, Ondo State, Nigeria
}

World Journal of Biology Pharmacy and Health Sciences, 2021, 05(01), 066-088

Publication history: Received on 18 December 2020; revised on 29 December 2020; accepted on 02 January 2021

Article DOI: https://doi.org/10.30574/wjbphs.2021.5.1.0108

\begin{abstract}
Since ancient times, plants with medicinal properties possessing no or little toxicological potentials have been relevant for the treatment of several diseases and healing purposes. Medicinal plants serve as important therapeutic agents and valuable resources for manufacturing numerous modern and traditional medicines. Many developing nations still rely on herbal remedies as their mainstay of health-care. This review study is aimed to report the trado-medicinal values of some ethnobotanical plants commonly used in traditional formulations as well as the scientific investigations of these plants for their acclaimed use in traditional practices. Essential phytochemicals and bioactive compounds of these plants are also reviewed.
\end{abstract}

Keywords: Ethnobotanical plants; Traditional medicine; Phytochemicals; Antioxidants; Alternative medicine

\section{Introduction}

Medicinal plants have been a major and essential resource in trado-medicine and modern drugs for treating and managing several human diseases and ailments [1]. Traditional medicine is the most easily accessible and affordable source of treatment in the primary health care system, most especially in rural and poor communities. In recent years, the use of traditional medicine derived from plants has received considerable interest due to the diversity and biological activities of naturally occurring secondary metabolites derived from plants, and the development of new and sensitive techniques to detect, isolate, purify and characterize plants' biologically active natural compounds $[2,3]$.

Several medicinal plants have been scientifically evaluated and validated for their applications in the management and treatments of several diseases and disorders like malaria, nephrolithiasis, liver problems, kidney pain, oedema, worm infestation, nausea, bronchial, jaundice and gastrointestinal disorders, rheumatism, muscle swelling, insect bites, ulcers, diabetes, and so on. Some of these important medicinal plants include Artemisia annua, Ficus vallis-choudae, Bouea macrophylla, Aspalathus linearis, Synedrella nodiflora and Nauclea latifolia etc. [3-6]; they are reviewed in this work.

Tracing of the medicinal value of plants and their bioactive substances that generate a definite physiologic action on the human body have been achieved through phytochemical screening $[7,8]$. Some important bioactive compounds in plants are the glycosides, flavanol, alkaloids, flavonoids, saponins, cardenolides, tannins, proanthocyanidins and polyphenolic compounds. These compounds are valued for their antioxidants and enzymes inhibiting activities and desirable for their roles in disease prevention and therapy $[3,9,10]$.

\footnotetext{
${ }^{*}$ Corresponding author: Kayode Damilola Adekeye; Email: damilola293@gmail.com

Department of Chemistry, Faculty of Science, Ekiti State University, Ado-Ekiti. 


\section{Traditionally used Medicinal Plants and their Values}

\subsection{Artemisia annua $\mathrm{L}$.}

Artemisia annua L. is herbaceous perennial herb also known as sweet wormwood belonging to the family Asteraceae. It is of Asia origin and widely dispersed throughout the world temperate region. It is widely applied in folklore medicine. A. annua is traditionally used to treat fevers, remove intestinal worms, gush menstruation, repel intestinal gases, treat hemorrhoids and boils, etc. [11]. The plant shows promising ethnopharmacological activities such as antifungal, antipyretic, antiplasmodia, anti-inflammatory and antioxidant [11]. A. annua is famously known for its application in treatment of malaria. It is the primary source of artemisinin, a sesquiterpene lactone possessing antimalarial activity. For the production of artemisinin, the plant is cultivated on a large scale in countries like Vietnam, China, Turkey, Iran, Afghanistan, Madagascar and Australia. Artemisinin based Combination Therapies (ACTs) comprising artemisinin, its derivatives like artemether, arteether, etc, and few long acting drugs like lumefantrine and amodiaquine are effectively used worldwide for the treatment of malaria caused by Plasmodium falciparum [11-13]. Various species of Artemisia, including A. annua, are characterized with essential oils that exhibit strong bio-herbicidal and insecticidal activities [6, $14,15,17,18]$.

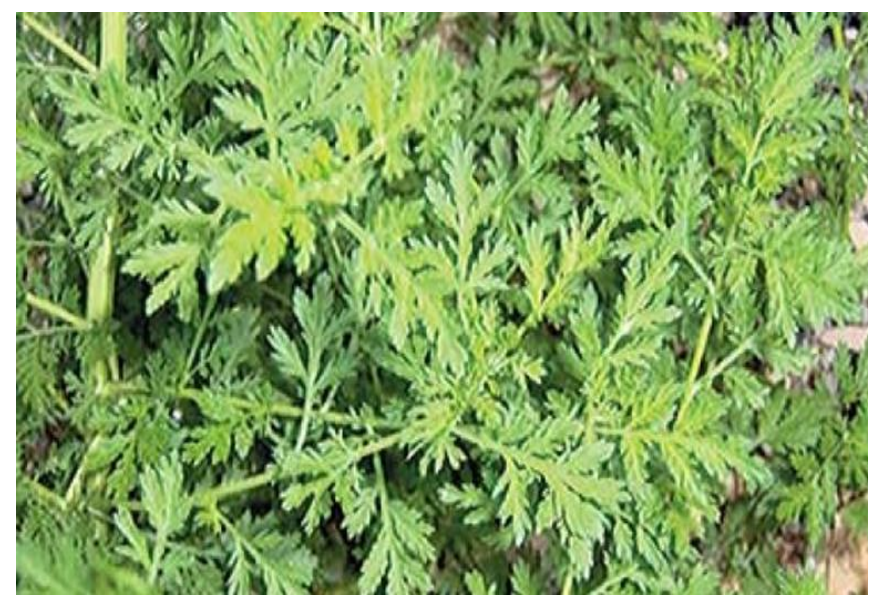

Figure 1 Artemisia annua leaves

\subsection{Ficus vallis-choudae Delile}

Ficus vallis-choudae D. is a tropical tree of the Moraceae family, with white latex [19]. Ficus vallis-choudae is known as a riverine fig tree. It is widely distributed in Tropical African countries like Nigeria, Senegal, Cameroon, Sudan, Malawi and Ethiopia [20]. According to Oliver [21], the leaves and young leafy stems are used as local drug for nausea, bronchial, jaundice and gastrointestinal disorders. The figs are edible and mostly appreciated by children in some parts of Africa [20]. The bark extracts of Ficus vallis-choudae in organic media have been reported to possess anticonvulsant and antifungal activities as well as anti-inflammatory and antinociceptive effects [4, 22, 23].

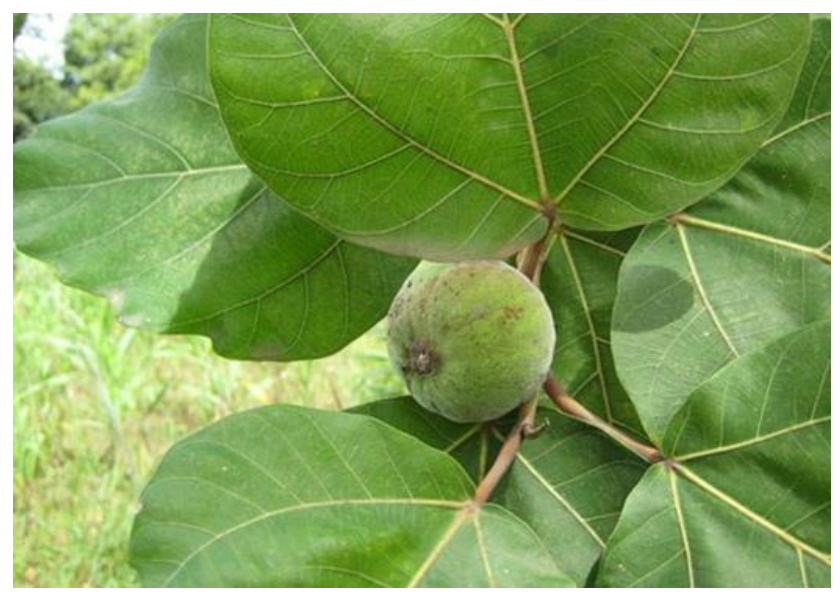

Figure 2 Ficus vallis-choudae leaves and fruit 


\subsection{Sorghum bicolor $\mathrm{L}$.}

Sorghum bicolor is commonly known as Sorghum. It is the fifth most commonly consumed cereal crop by human after rice, wheat, corn, and barley. The majority (about 65\%) of cultivated Sorghum is commonly used to make animal feeds and industrial products, while about $35 \%$ of it is directly consumed by humans. It is a plant that is well grown across Asia, Africa and America. It is a member of the plant family Poaceae and is well-known for its diverse phytochemical composition possessing antioxidant properties and effectiveness in cholesterol control [24]. In trado-medicine, the stem is used to treat anaemia and blood related ailments; it also possess both an anti-malarial and anthelminthic properties [25].

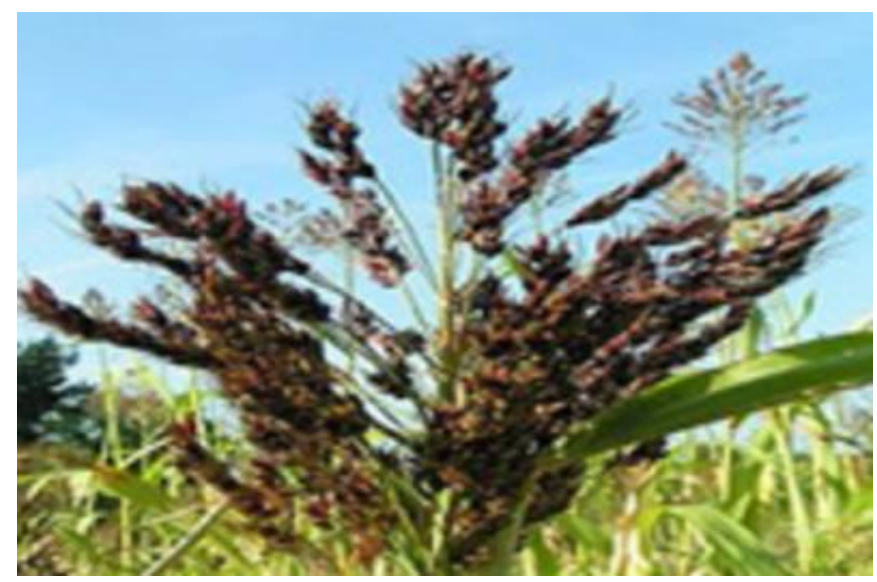

Figure 3 Sorghum (Sorghum bicolor)

\subsection{Theobroma cacao}

Theobroma cacao is a tree usually cultivated in some West African Countries like Ghana and Nigeria, and predominantly cultivated in Brazil for its industrial value. It belongs to the family Malvaceae and is popularly called Cocoa tree. The seed is the main source of chocolate; the ash from pod from the pod is used as source of lye for soap making. Cocoa butter extracted from the seed of cocoa is used in cosmetics and formulations for skin care products.

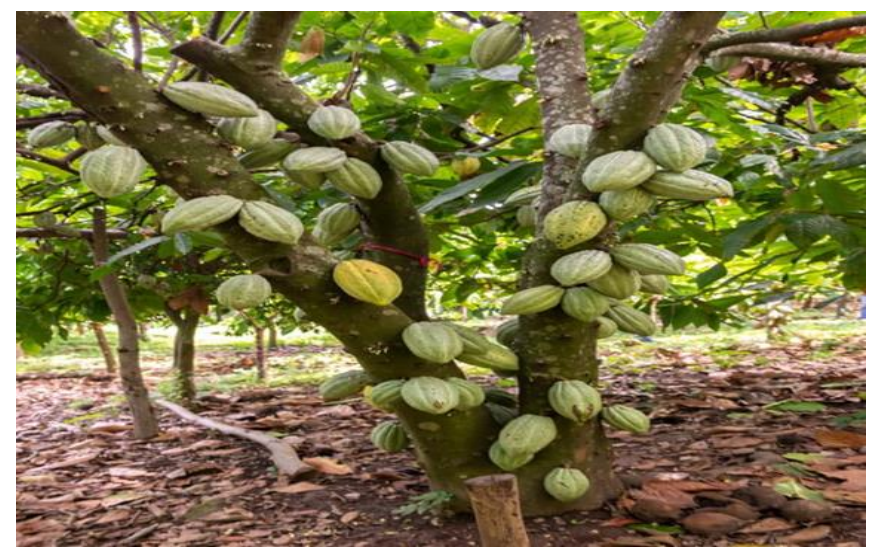

Figure 4 Theobroma cacao plant

The seed of cocoa has been evaluated for its phytochemicals and has been found to contain a high content of important bioactive compounds like phenolics, flavonoids and theobromine which are important antioxidants [26]. Chocolate was found useful for healthy function of the spleen and stimulating other digestive functions. In the 17 th and 18 th centuries, chocolate was recommended or mixed into medications for various kinds of diseases and ailments, to enhance digestion, reinforce mental performance, improve fertility and as an antidepressant remedy [27]. Cocoa products are also rich in methylxanthines such as caffeine and theophylline which are known possess both negative and positive health effects. For instance, caffeine intake has been reported to have negative effects on mental and reproductive health while, its supplementation enhanced net hepatic glucose uptake through increment of glucose-6- phosphate production in the liver [27]. Insufficient iron in the diets results to iron deficiency anaemia, a condition in which the red blood cells 
becomes low in hemoglobin and correspondingly carry less oxygen [28]. In Nigeria, a mix of Sorghum bicolor sheath and Theobroma cacao stem bark extracts of water and/or alcohol are used to treat anaemia.

\subsection{Centaurea austro-anatolica}

Centaurea austro-anatolica is a 30-60 cm tall perennial herb with branches, tomentose and hairy leaves as well as pink flowers. The plant belongs to the family Asteraceae. It mostly grows in Antalya and Muğla Provinces in Turkey [29]. While several species of the genus Centaurea are widely applied in ethnomedicines for the treatment of diarrhoea, diabetes, hypertension, microbial infections, rheumatism and ulcers [30-32], there is little or no report on any medicinal uses of $C$. austro-anatolica in folklore medicines in Antalya, Muğla or Konya provinces. There is a report on GC-MS based volatile component analysis and antimicrobial activity assessment of $C$. austro-anatolica [32].

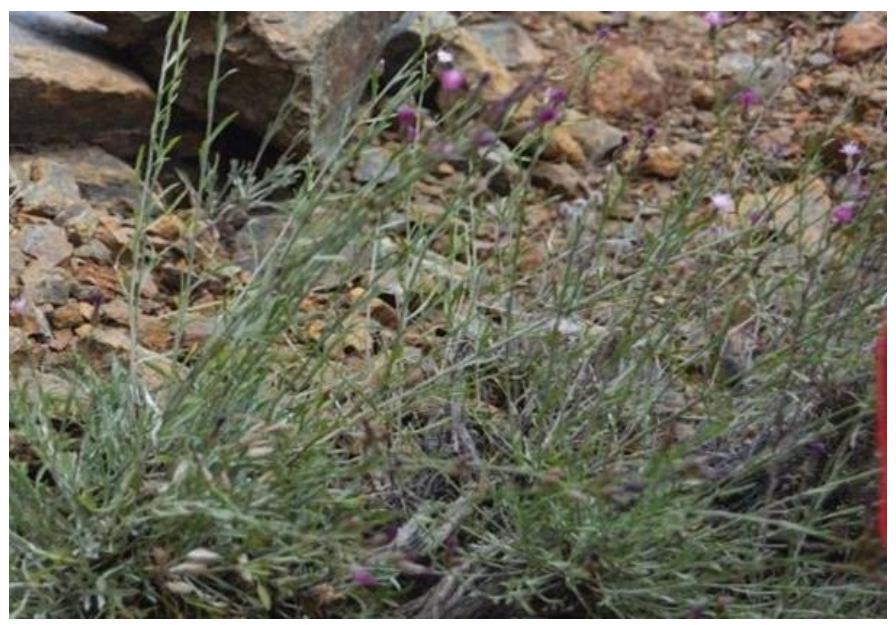

Figure 5 Centaurea austro-anatolica plant

\subsection{Fraxinus excelsior $\mathrm{L}$.}

Fraxinus excelsior L. also known as European ash or common ash is widely distributed in Europe and usually cultivated as an ornamental plant in Canada, New Zealand and United States. It belongs to the Olive family Oleaceae. Fraxinus excelsior is a large tree that grows up to $40 \mathrm{~m}$ tall, with ascending branches, pale grey smooth bark, serrated and stalkless; flowers usually open before the leaves unfold; flattened seeds of about 2-5 cm long in bunches and ripen individually [33].

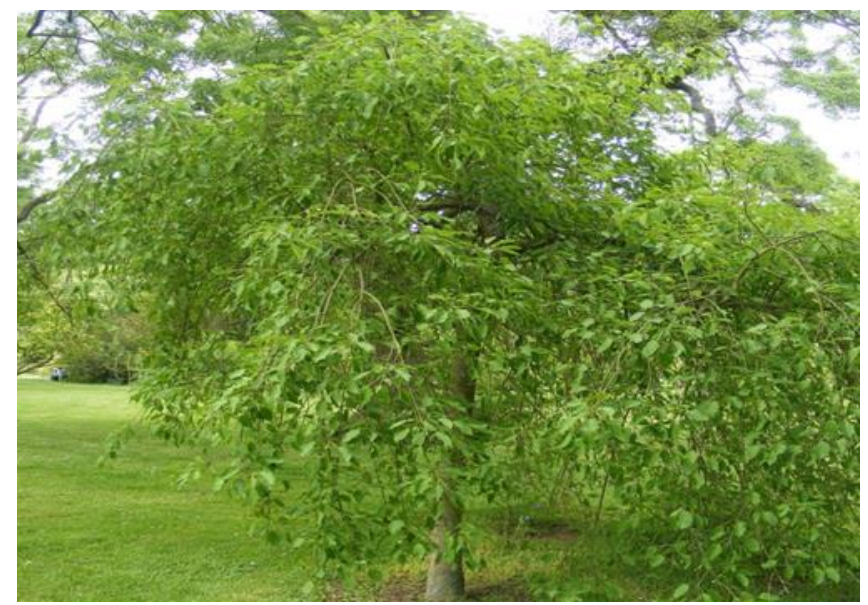

Figure 6 Fraxinus excelsior plant

The bark is used to treat arthritis, dysentery, gout, diarrhoea, rheumatism, sores, swelling and wounds. It is essential substitute for quinine in malaria treatment. Its leaves are highly medicinal and taken as a laxative, diuretic, and recommended for the treatment of fever, rheumatism, gout, stones, constipation, jaundice, nephrolithiasis, liver problems, kidney pain, oedema, cervical pain, worm infestation and urinary stones; and externally for wounds and leg 
ulcers [34-39]. The plant sap is a useful antidote for snake bites. The investigated phytochemical studies on the leaves showed the presence of essential bioactive compounds like coumarins, iridoids, rutin, kaempferol and quercetrin- 3-0glucoside, seco-iridoids, their respective 3-0-rhamnoglucosides, betulin, $\beta$-sitosterol, betulinic acid and ursolic acid [34, $38,40,41]$.

\subsection{Senna sulfurea (Collad.)}

Senna sulfurea (Collad.) which is known as glossy sulphur-flowered senna, glaucous cassia, kalamona, and smooth senna, is distributed in India, Sri Lanka, Australia, Polynesia, south eastern Asia, Gabon and China. It is a member of the family Caesalpiniaceae and is commonly planted as ornamental plant due to its beautiful flowers. It grows up to $3 \mathrm{~m}$ high. Its young shoots are hairy and later become hairless. It's an evergreen, perennial shrub or small tree, with 15$30 \mathrm{~cm}$ leaves, 3.5-6.5 cm leaf stacks; yellow flowers and flat strap shaped pods with black shiny seeds [42]. The leaves find folksforic application in curing of blennorrhagia when mixed with milk and sugar. The bark and leaves contain antioxidants that are useful to relieve diabetes and are used to treat dysentery and gonorrhea [42, 43]. The flowers and pods are purgative; the pods are prepared and used an antiseptic to manage skin diseases [42].

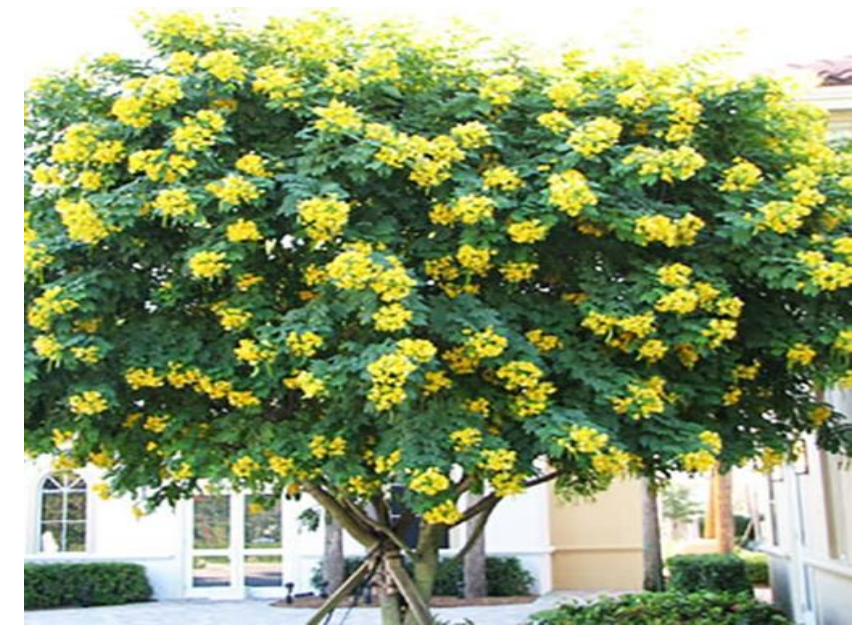

Figure 7 Senna sulfurea plant

\subsection{Prosopis cineraria (L.) Druce}

Prosopis cineraria (L.) Druce, also known as called as Indian mesquite and sponge tree, is widely distributed in Asian countries like India, Iran, Afghanistan, Oman, Sri Lanka, Saudi Arab, Pakistan and Yemen. It is member of the family Leguminosae and grows up to $5 \mathrm{~m}$ tall tree, with bipinnate leaves consisting of 7-14 leaflets on each of one to three pinnae.

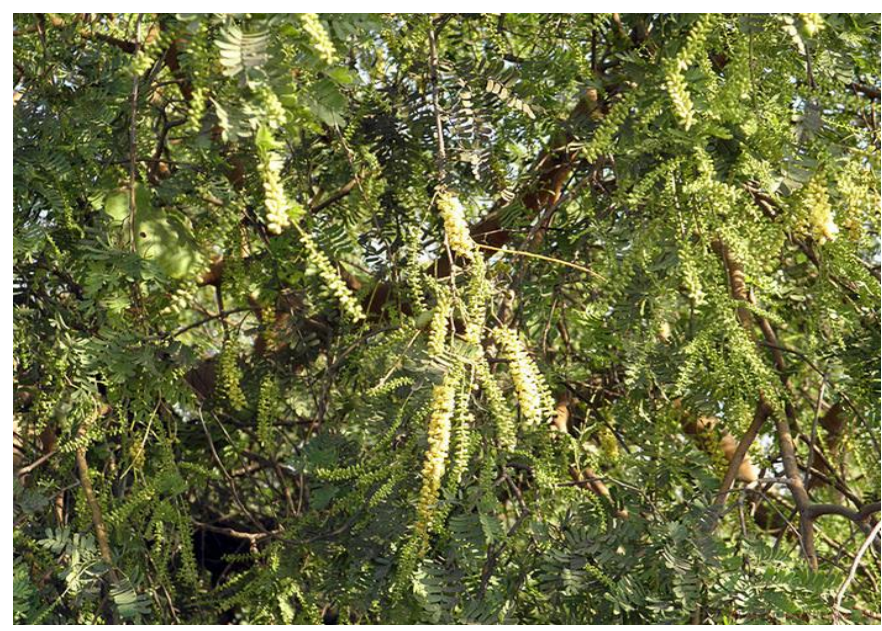

Figure 8 Prosopis cineraria leaves 
The tree is characterized by its thorny branches along the internodes; small, creamy-yellow flowers; seeds in pods. The bark is considered as an abortifacient, anthelmintic, laxative, refrigerant, tonic and vermifuge, used to treat anxiety, asthma, bronchitis, dysentery, dyspepsia, fever, leprosy, leucoderma, muscle tremors, piles, rheumatism and tremors [44]. A leaf paste is applied to cure boils, blisters, sores and mouth ulcers. Smoke from the leaves is suggested for eye troubles [45]. The plant material is used to treat snake bite and scorpion sting. The wood ash is rubbed over the skin to remove hair. [46]. A pod extract is used to relieve earache, toothache and fractured bone pain [47].

\subsection{Bouea macrophylla Griffith}

Bouea macrophylla belongs to the Anacardiaceae family and is related to mangoes [48, 49]. It is commonly known as the Mariam Plum or Plum Mango. It also has been shown as an evergreen and a perennial tree that grows up to 25 meters of height, highly seasonal and is widely distributed in South East Asia including Malaysia, Indonesia, Laos, Thailand, Java, Myanmar, and Sumatra [50]. The leaves and fruits are edible, popularly eaten in local communities of Sabah, Malaysia and Sarawak [51]. The plant is widely cultivated in Malaysia for shade as well as for ornamental purpose [50]. Traditionally, almost all parts (seeds, unripe and ripe fruits, and leaves) of the plant have been used for various culinary purposes [49]. Ripe fruits of B. macrophylla have sweet taste and have found various applications in preparing snacks, beverages and jellies. On the other hand, unripe fruits with sour taste are used as vegetable [48]. In Indonesia and Malaysia, the tender leaves of the plant are used as a raw vegetable in the preparation of salads [50]. A successful study has been undertaken to show the phytochemical constituents of B. macrophylla Griffith as well as its antioxidant activity [52].

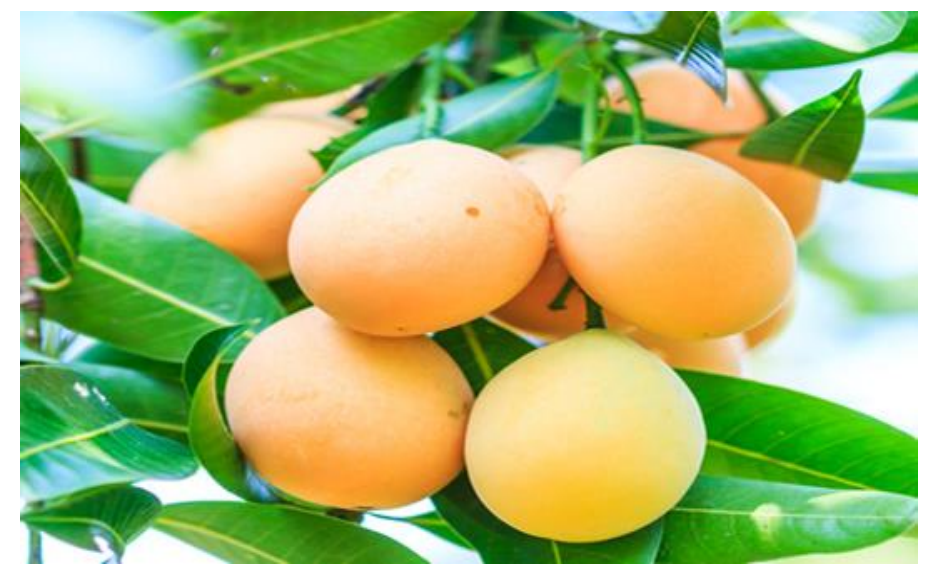

Figure 9 Bouea macrophylla leaves and fruits

\subsection{Myrtus communis $\mathrm{L}$.}

Myrtle (Myrtus communis L.) is a plant that belongs to the Myrtaceae family, a shrub native to the western Asia and Mediterranean countries [53]. It is commonly known as myrtle. Historically, ancient Mediterranean populations used myrtle for its aromatic and ornamental values [53]. Myrtle fruits have a long history of application as a food ingredient in place of pepper; as a spice for meat cooking and tendering; as food integrators (because of its high vitamin contents) [54]. The fruit decoction or infusion of this plant is used in folk medicine as hypoglycemic, stomachic, anti-microbial agent, and to treat cough and oral diseases [54]. It is also used to treat constipation, for appetizing, anti-hemorrhagic and externally for wound healing [54]. In recent years, the greater part of myrtle produced in the Mediterranean area are used for preparation of liqueur [56]. The nutraceutical and antioxidant properties of $M$. communis have made it found applications in cosmetic, food and pharmaceutical $[57,58]$. Many studies have been reported on the essential oil composition of the plant [59-64]. The pharmacological values of this essential oil have been explored in recent years. The plant is found to possess anti-microbial properties, anti-hyperglycemic and antioxidant activities [5, 61-63, 65-68]. 


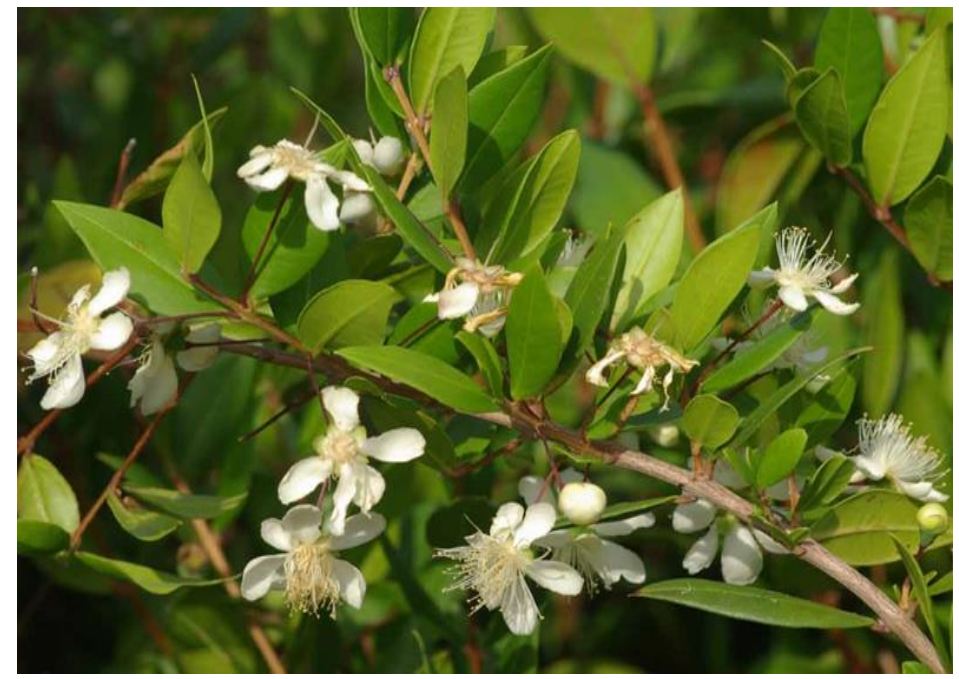

Figure 10 Myrtus communis leaves and flowers

\subsection{Premna mucronata Roxb}

Premna mucronata Roxb commonly known as, "Ganiar", "Bari arani", "Agnimatha”, Agethu" and "Agyon", is a low bushy tree (with trunk up to $1.2 \mathrm{~m}$ height) of great ethnobotanical value belonging to the family Verbenaceae. Furthermore, $P$. mucronata is a medicinal and aromatic plant and one of the important ingredients of "Dashamula" herbal preparation [69]. The bark finds application in curing boils while the leaves have been applied externally to treat dropsy as diuretic $[70,71]$. Savasani et al. [72] reported that $P$. mucronata showed cardioprotective activity in myocardial infarction due to its antioxidants composition. It also possesses larvicidal properties Renjana and John [73]. Antimicrobial, hypocholestremics and wound healing ability as well as anti-inflammatory activities have been demonstrated by this plant [74-76]. Recent studies showed that its essential oil has remarkable antifeedant properties [71, 74]

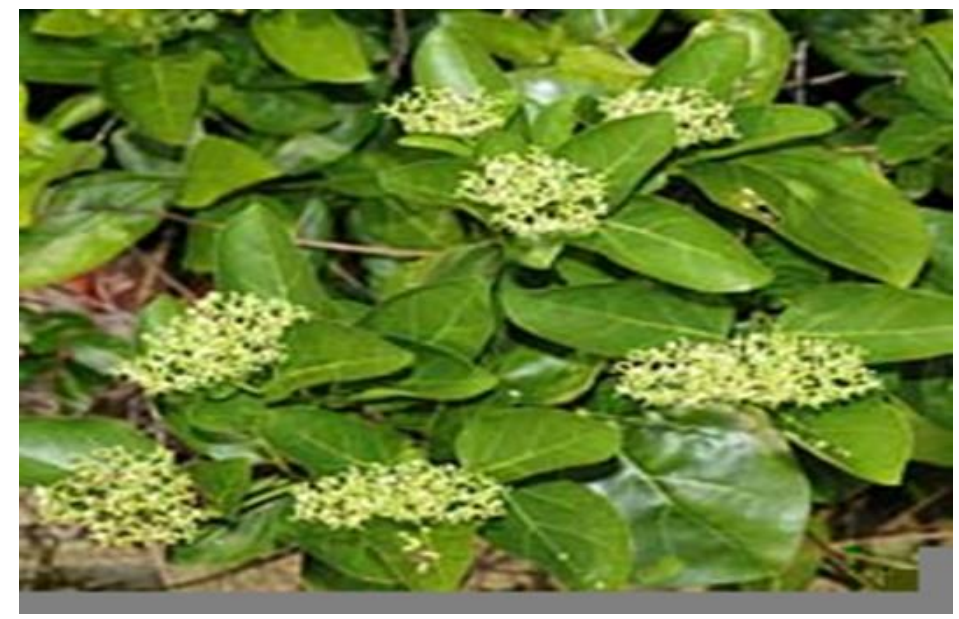

Figure 11 Premna mucronata Roxb

\subsection{Annona mucosa Jacq}

Annonaceae is a group of shrubs, aromatic trees and lianas that occur mainly in subtropical and tropical and [77]. It exhibits a pan tropical distribution with 40 genera and about 900 species in the Neotropical region [78]. Despite its diversity, Annonaceae constitutes one of the lesser phytochemically investigated tropical plant families [79]. It is one of the best natural products with insecticidal properties, especially due to the high level of allelochemicals that accumulate in different parts of the plant [78]. Several species of the genus Annona have been used in traditional medicine for pest control and the treatment of various ailments. For instance, Annona muricata L. leaves are widely used in the treatment of diarrhea and arthritis [80]. Annona mucosa (Fig. 12) is a medicinal species from the family Annonaceae, a fruit tree that grows well in different habitats though native in Atlantic and Amazon forests [81]. Annona mucosa grows to a height ranging from $1 \mathrm{~m}$ to $4 \mathrm{~m}$, has brown hairy twigs with 1 to 3 flowers forming together in the leaf axils. The fruit (usually $15 \mathrm{~cm}$ in diameter) is conical or heart-shaped and is [82]. Annona mucosa Jacq leaves are extensively applied against 
fleas and other insects [77]. Annona reticulata Linn whole plant is used to control of fever, treat ulcers, and diarrhoea [83]. Annona squamosa L. fruits, leaves and roots are used to overcome fainting and hysteria and relief for vomiting; the plant is used as an expectorant and to treat spinal disease [84]. Phytochemicals like flavonol, flavonoids and glycosides have been isolated from various parts of the plant [85]

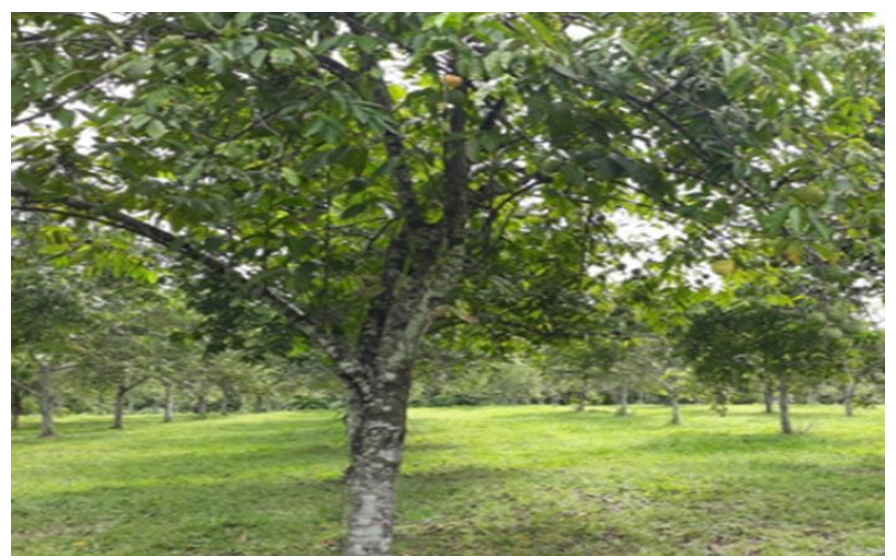

Figure 12 The photograph of Annona mucosa trees

\subsection{Ficus exasperate Vahl.}

Ficus Linn. genus, belongs to the family Moraceae which consists of over 800 species of and shrubs trees a shrubs and trees throughout tropical and warm temperate regions. They are well-known all over the world as "fig plants or fig trees" $[86,87,88]$. The specie Ficus exasperate Vahl. is an evergreen forest tree that grows up to $20 \mathrm{~m}$ height and widely distributed in Zambia, Mozambique, northern Angola, Ethiopia, Senegal and central African countries [89]. It is popularly known as "sand paper tree" due to its leaves' scabrous surface. The leaves is widely used as an abrasive for polishing hard surfaces such as furniture and utensils [90-92] Ficus exasperata Vahl. is a useful medicinal plant of biological values for the treatment of many diseases in different parts of Africa. In Cameroonian folk medicine, the leaves are used in the treatment of malaria, hemorrhoids and diarrhea when the water extract is administered orally [93-95]. In Ivory Coast, the viscid sap is used for the treatment of sores and stomach pains [96]. Studies on the stem barks, leaves and root extracts of $F$. exasperata have shown the promising antimicrobial potentials of the plant [86, 97]. Antiinflammatory, anti-nociceptive and antipyretic activities of the hydro-alcoholic extract of the plant's leaves have been reported [98]; while the stem-bark hydro-alcoholic extract showed antiulcerogenic, antioxidant, hypotensive, lipid lowering and hypoglycaemic activities [91]. The plant is rich in phytochemicals namely alkaloids, flavonoids and tannins among others [90].

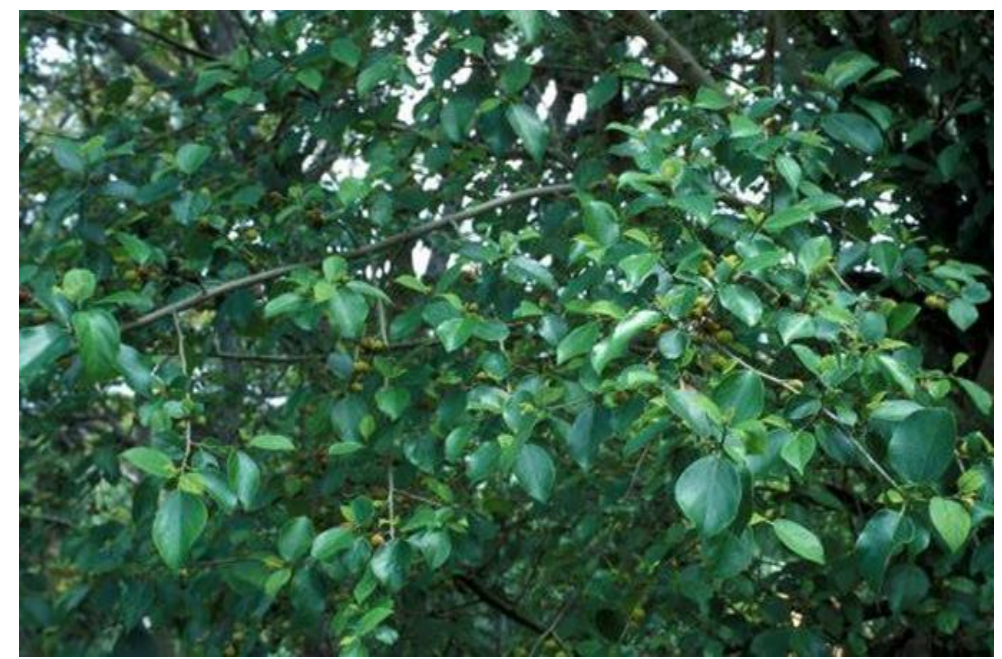

Figure 13 Ficus exasperate leaves 


\subsection{Triclisia subcordata (Oliv)}

Triclisia subcordata (Oliv) is a flowering plant in the Menispermaceae family. It is predominantly found west tropical African countries including Ivory Coast, Nigeria, Senegal, Ghana, Sierra Leone and Togo [99]. The plant primarily serves as rope used for tying purposes while the importance of the species however rest with their medicinal applications. The root extract finds folksforic applications in the treatment of ulcer, snake bite, diarrhea, malaria, and pyorrhea, anemia joint pains, swelling of extremities, rheumatic pains and hypertension in Nigeria [100, 101]. The plant has also been evaluated for its enzymes inhibition activities, antiulcer, antihistamine, antimicrobial, antioxidant, anticancer, and antidiabetic activities $[8,10,15,102-104]$

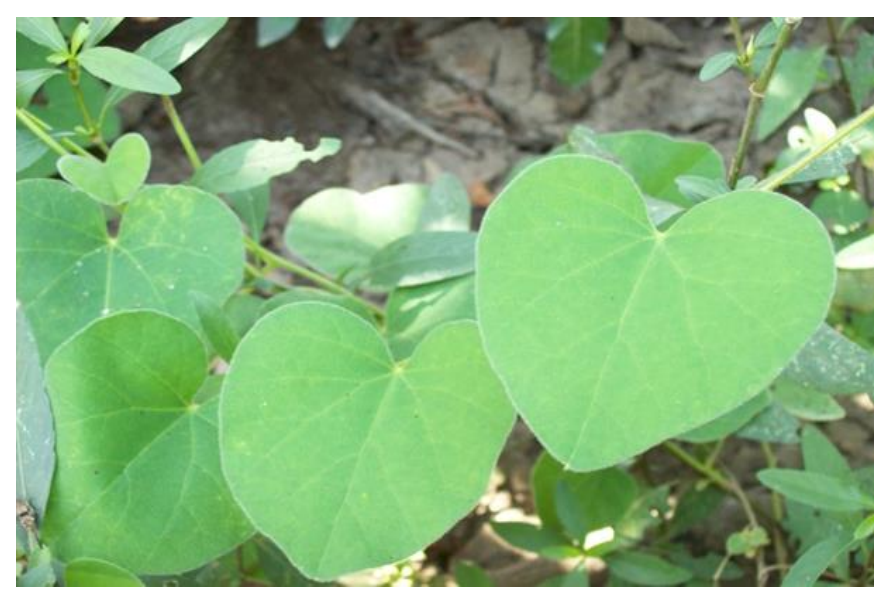

Figure 14: Triclisia subcordata (Oliv)

\subsection{Aspalathus linearis (Brum.f Dahlg.)}

Aspalathus linearis (Brum.f Dahlg.) which is globally known as rooibos is a plant belonging to the family Leguminosae that grows naturally in the Cederberg Mountains in the western parts of the Western Cape Province, South Africa. The rooibos plant has gained transition from being a wild resource to become a plant of great economic and biological importance [105]. Rooibos is cultivated and usually processed to tea. After harvesting, the plant material may be subjected to a fermentation process which involves bruising and oxidizing it in open air. The processed tea is usually referred to as fermented rooibos, while the unprocessed tea is referred to as unfermented or "green" rooibos Joubert and De Villiers [106] with total production including unfermented rooibos was in excess of 14,000 tons [107]. Rooibos tea is believed to possess antispasmodic properties, as well as ability to relieve digestive troubles among others [108, 109]. Rooibos have a unique flavonoid composition, containing rare compounds as previously described. Both the fermented and unfermented rooibos possess good antioxidant activities and tyrosinase inhibitory activity as an indication of having diverse health promoting properties, especially to solving problems associated with oxidative stress [3]. The plant contains essential bioactive phytochemicals like flavonoids flavonol, phenolics, tannins and flavanols $[3,110,111]$

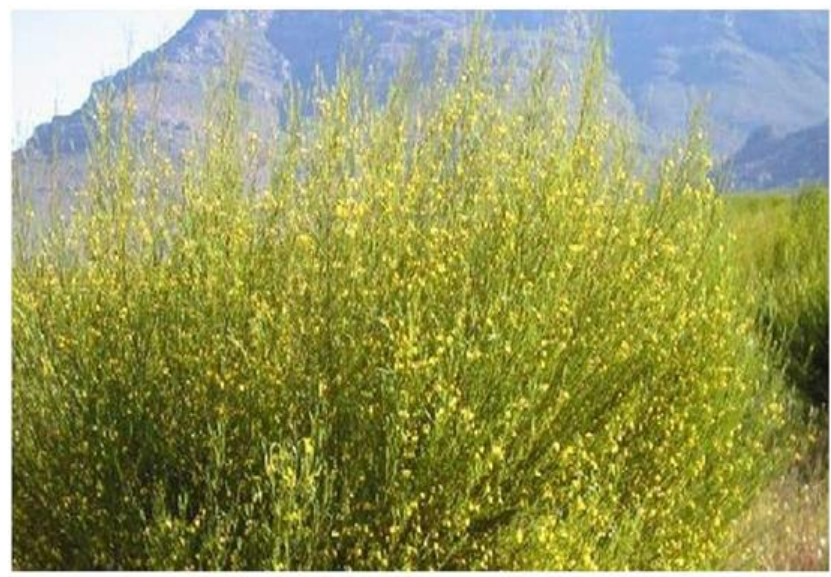

Figure 15 Aspalathus linearis plant 


\subsection{Nauclea latifolia smith}

Nauclea latifolia smith is a plant that belongs to the family Rubiaceae; it is an evergreen plant commonly called African peach. It is a multi-stemmed small tree or shrub native to tropical Africa and Asia [112]. Nauclea latifolia is a valuable ethnomedicinal plant that is widely spread in the humid tropical rainforest zone or in savannah woodlands of Central and West Africa. N. latifolia is commonly known as African peach and is used in traditional medicine in the Western and Eastern sub-region parts of Africa [100, 113]. Various extracts of the plant parts are used for the therapeutic management of hypertension [114]; malaria [115]; prolonged menstrual flow [116]; gonorrhoea, cough, stomach aches, ulcers, dysentery and liver ailments $[113,117]$. In West African countries, the plant is commonly used to treat diarrhea, jaundice, dental caries, septic mouth, hypertension, gastrointestinal disorders and diabetes $[116,118,119]$. In addition, it is used to treat sleeping sickness and prolonged menstrual flow in Nigeria [116]. N. latifolia is known as 'Africa cinchona' or 'Africa quinine' because of its anti-malarial activity [120]. Cold infusion of the leaves and the stem bark are used as anti-helmintic to regularly deworm animals and as diuretic in Northern Nigeria [121, 122]. The root is a major ingredient in Nigerian tradomedicine for treating respiratory problems such as asthma, bronchitis, cough and cold [123]. The most frequently used plant parts are the roots, followed by the stem, bark, and leaves.

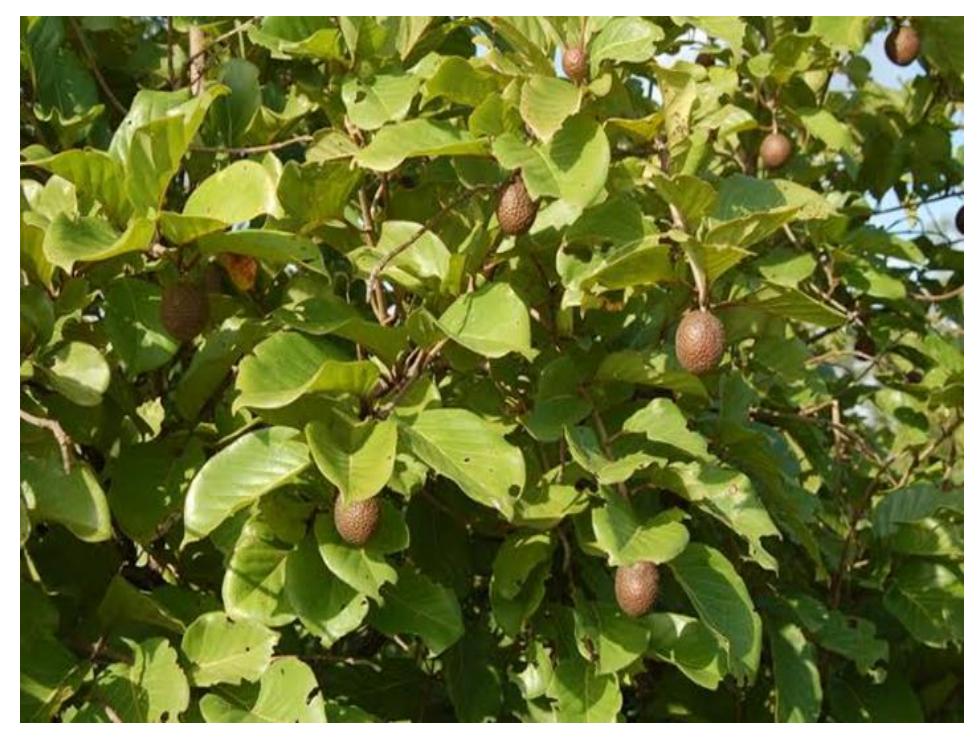

Figure 16 Nauclea latifolia plant

\subsection{Vicia faba $\mathrm{L}$.}

Vicia faba L. (broad bean) is a leguminous plant that belongs to the plant family Fabaceae. The plant is rich in polyphenols, with its beans a popular food in many countries. It is an essential winter crop in Mediterranean areas and is mostly a spring crop in other regions of South America and Europe; it is one of the major plant food items among the Nile River populations [124]. Fava beans are nutritious and very high in protein content as in other beans and lentils. The beans are rich in antioxidants, minerals, vitamins, and plant-sterols. Phytochemicals such as genistein and daidzein present in fava beans have been found to protect breast cancer in laboratory animals; $\beta$-sitosterol (a phytosterol) helps lower cholesterol levels in the body [125]. However, only the seeds are used in human nutrition, while the whole plant is used animals feed. The plant is used in folk medicine as antihyperlipidimic to control cholesterol [126]. $\mathrm{V}$. faba L. seed is found to contain a high number of bioactive compounds such as glycosides ( $\alpha$-galactosides, vicine and convicine), proteins (protease inhibitors, $\alpha$-amylases, lectins), saponins, tannins and alkaloids [127]. In a research by Boukhanouf et al. [128], immature faba bean fractions showed significantly higher phytochemical contents and displayed a better antioxidant activity than those of mature ones. 


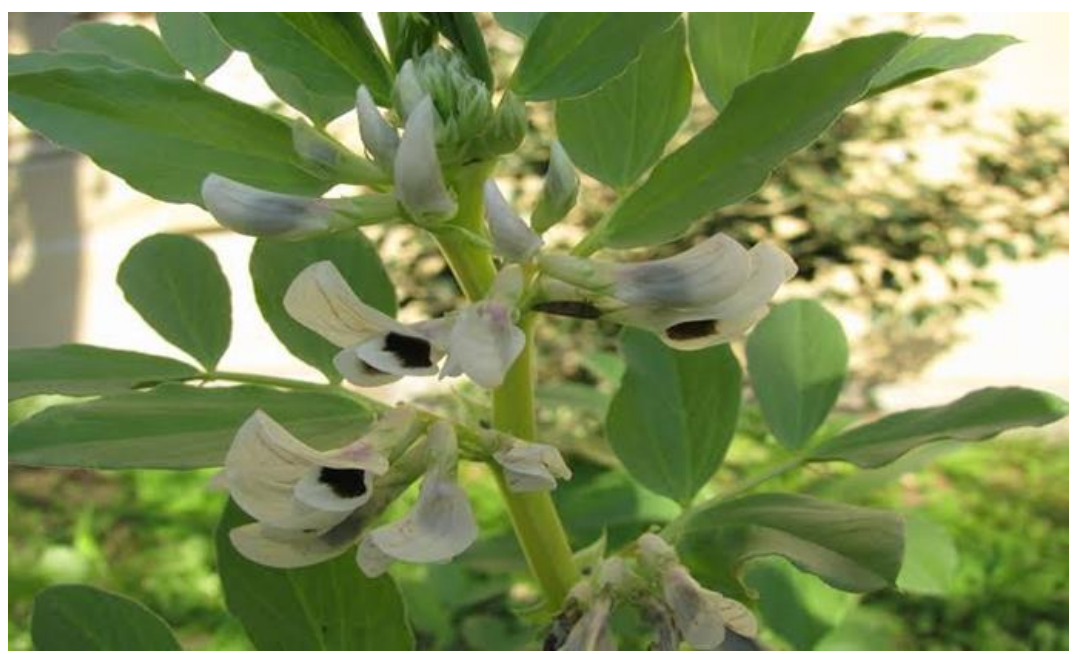

Figure 17 Vicia faba plant

\subsection{Pterocarpus soyauxii Taub}

Pterocarpus soyauxii Taub (Fabaceae) which is commonly known as African Coral-wood is a popular green vegetable often utilized in the South Eastern part of Nigeria due to its high vitamin C content and unique taste [129, 130]. Crude extract of the leaf could potentially increase white and red blood cells as well as haemoglobin [131]. The plant has found wide tradomedicinal applications in treatment various diseases such as renal infections, hypertension, chronic anaemia, fungal infections and skin diseases [132-134]. Phytochemical investigations of Pterocarpus soyauxii Taub revealed the presence of flavonoids, bioflavonoids, ascorbic acid and pterostilbene [135-138].

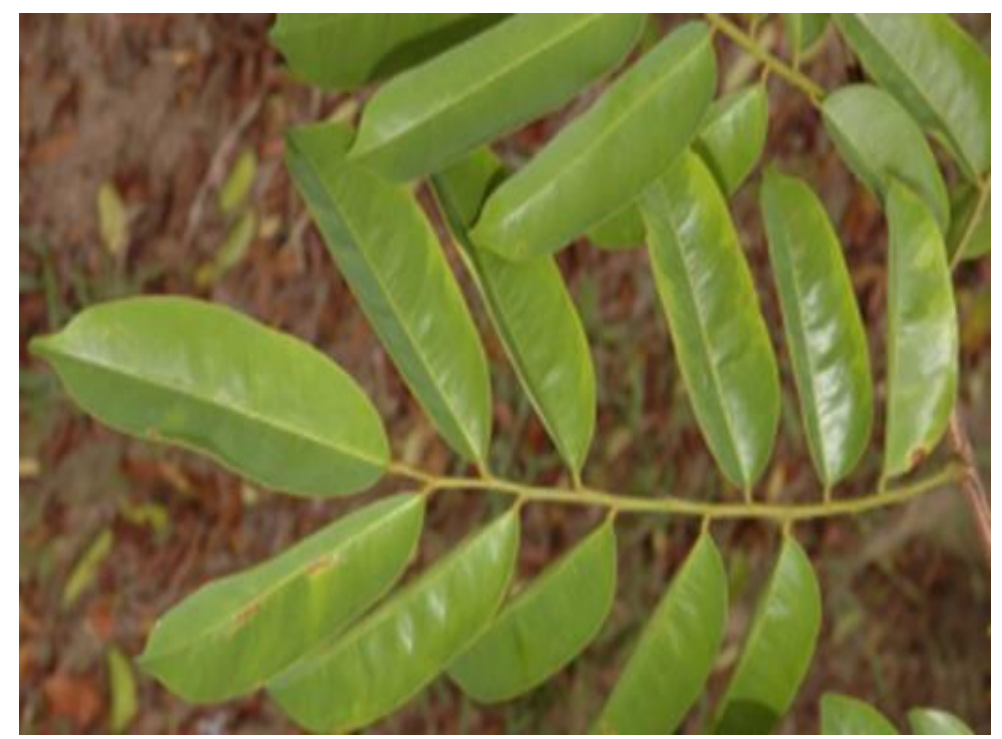

Figure 18 Fresh leaves of Pterocarpus soyauxii plant

\subsection{Withania coagulans (Stocks) Dunal,}

Withania coagulans (Stocks) Dunal, is a native plant to Afghanistan, Iran and Indian. Within the Withania genus, $W$. coagulans (Ashutosh booti) and W. somnifera (Ashwagandha) are economically significant for their medicinal values and distributed in several regions ranging from east of the Mediterranean region to South Asia. W. coagulans is common in many parts of India Afghanistan, Pakistan and Nepal [139]. W. coagulans is a rigid grey-to mentose undershrub, 30$120 \mathrm{~cm}$ tall; leaves are lanceolate oblong and sometimes ovate, obtuse and thick. flowers are 7-12 mm in diameter and yellow, (Fig. 1). The plant is propagated by seed; its flowering period is from January to April, while its berries ripen in May [139]. W. coagulans is used as a blood purifier, an anti-cancer drug, to treat diabetes, cure debility, impotence, insomnia and nervous exhaustion; it is externally applied as a therapy to relieve inflammatory conditions, scabies and ulcers [139]. The plant is used to make oil ointment capable of curing several skin diseases when mixed with 
Ashwagandh powder [139]. It works as an antidote to scorpion sting (Gupta and Singh, 2018). Different parts of plant are applied to treat rheumatism, ulcers, senile debility and dropsy. The fruits are blood purifier, diuretic, emetic, alterative, hepatoprotective, hypolipidemic, hypoglycemic, milk coagulant, sedative, sweet, stomachic and biliousness, used to treat diabetes, asthma, dyspepsia, skin rashes, intestinal infections, stomachache, strangury and wounds. The fruits extracts alongside W. somnifera are used to prepare a composite Ayurvedic medicine 'Liv 52' which is a hepatoprotective herbal formulation [140,42]. The twigs are chewed for cleaning of teeth and to relief toothache [141]. The flowers water extract is taken to control diabetes [142]. The bitter leaves are alterative and febrifuge. The seeds are diuretic anti-inflammatory and emetic $[143,144]$. Studies on antimicrobial, antiumor, antiinflammatory, Antimutagenic, antihyperglycemic, hepatoprotective, cardiovascular, free radical scavenging, immunosuppressive and central nervous system depressant activities of the plant parts have been reported [145-147]. The plant extracts showed the presence of saponins, alkaloids, phenolic compounds, steroids, tannins, proteins, an essential oil, milk-coagulating enzyme, carbohydrates, fatty oil, organic acids and amino acids [140, 148]

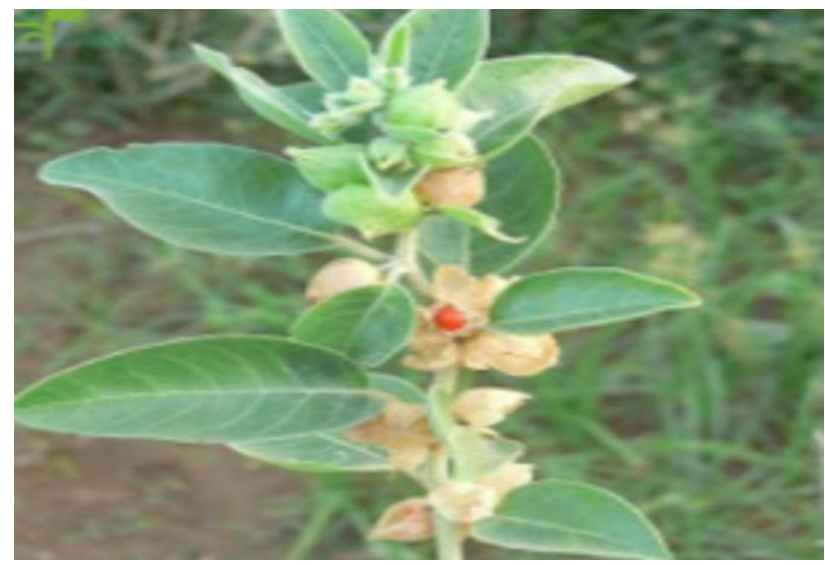

Figure 19 Withania coagulans plant

\subsection{Zingiber officinale}

The Zingiber species are noted for the various biological activities they exhibited. Some Zingiber species found growing in Ninh Bình Province was shown to have possessed essential oil $[149,150]$. Zingiber zerumbet rhizome oil displayed larvicidal activity against Aedes aegypti, Aedes albopictus and Culex quinquefasciatus [151]. . In addition, both Z. collinsii and Z. zerumbet extracts and essential oils possess larvicidal and antimicrobial properties [152, 153]. Zingiber officinale is an evergreen rhizomatous herb forming small clumps (ginger root) that is widely used as spices and in folk medicine. It is commonly known as ginger and belongs to the family Zingiberaceae. The creeping aromatic rhizome (ginger) grows up to $1.5 \mathrm{~cm}$ in diameter, internally cream white or yellow and externally light brown. The plant is an herbaceous perennial that has glossy translucent green leaves that are glabrous and false stems made of rolled bases of leaves. It is mostly cultivated in India, China, Nepal, Indonesia, Thailand and Nigeria. Flowering period ranges between July and September. The plant has a numerous phytochemicals responsible for its medicinal properties. The plant is traditionally used to treat arthritis, inflammation, diabetes, bacteria and fungi infections [151].

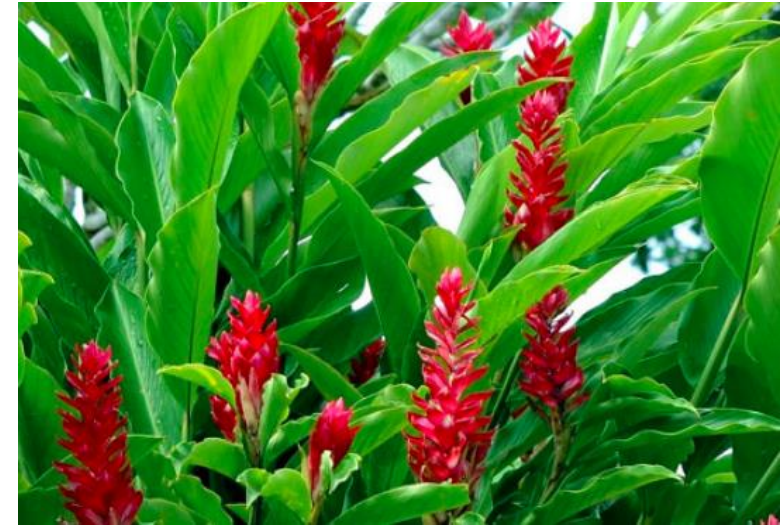

Figure 20 (a) Zingiber officinale plant and

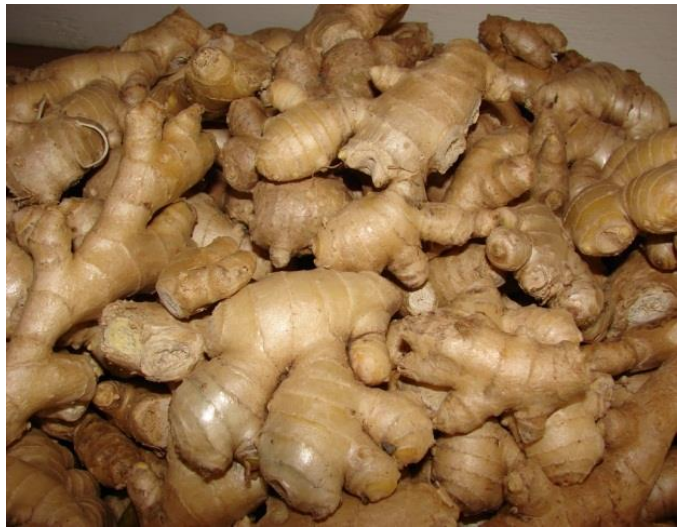

(b) Zingiber officinale rizhome (ginger root) 


\subsection{Phyllanthus niruri Linn}

Phyllanthus niruri Linn belongs to the family Euphorbiaceae and is an annual herb that is widely spread throughout the subtropical and tropical countries of the world including India and Sri Lanka. It is an important ethnobotanical plant of the Ayurveda system of medicine mentioned in all the relevant ancient Ayurvedic texts [154]. It is commonly found growing as weed in both cultivated and wasteland areas particularly in the rainy season. P. niruri Linn is commonly known as, 'Chancapiedra' (stone breaker), 'Gale of the wind' and 'Seed under a leaf' according to its pharmacological activities and morphology [155]. It is stated that the plant's extract is one of the most widely used remedies in Ayurveda system of medicine especially for anaemia, bronchitis, skin diseases, cough, kidney, liver, asthma and urinary tract disorders [156]. P. niruri Linn has a growing value as researches have uncovered more of its medicinal properties in recent years [154]. The plant demonstrates antimicrobial, anti-inflammatory and anti-diabetic activities, antiviral activity against hepatitis B virus, litholisis action of kidney and gall bladder stones, hepatoprotective activities, lipid lowering and immunomodulatory activities [157-162].

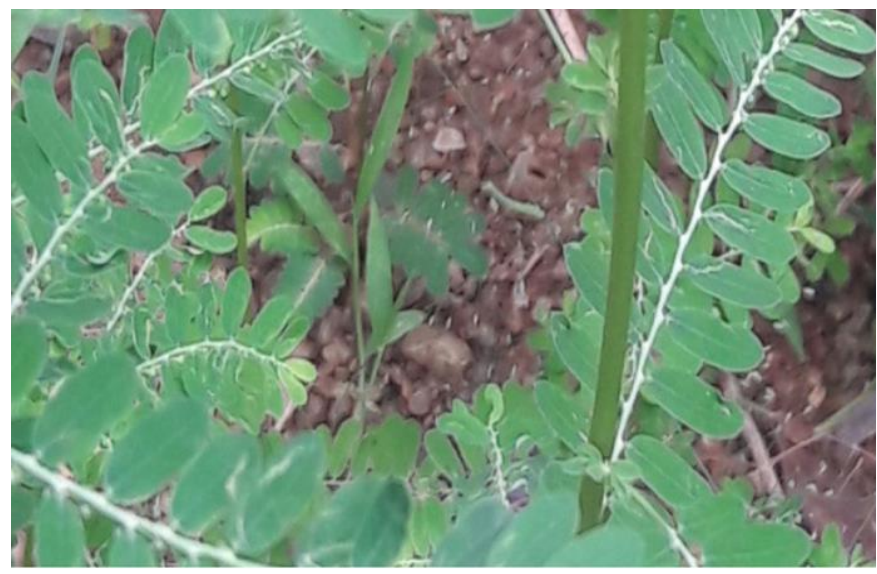

Figure 21 Phyllanthus niruri leaves

\subsection{Synedrella nodiflora}

Synedrella nodiflora is from the kingdom Plantae, infrakingdom of Streptophyta, subkingdom of Viridiplantae, division of Tracheophyta, subdivision of Spermatophytina, superdivision of Embryophyta, class of Magnoliopsida, order of Asterales, superorder of Asteranae, family of Asteraceae, genus of Synedrella Gaertn., and species of Synedrella nodiflora (L.) Gaertn [163]. S. nodiflora is a branched ephemeral herb that can grow up to $80 \mathrm{~cm}$ in height. It is has a shallow root system that is usually strongly branched. The leaves exist in opposite pairs and are usually 4-9 cm long while the lower part of the stem may root at the nodes, especially in moist conditions.

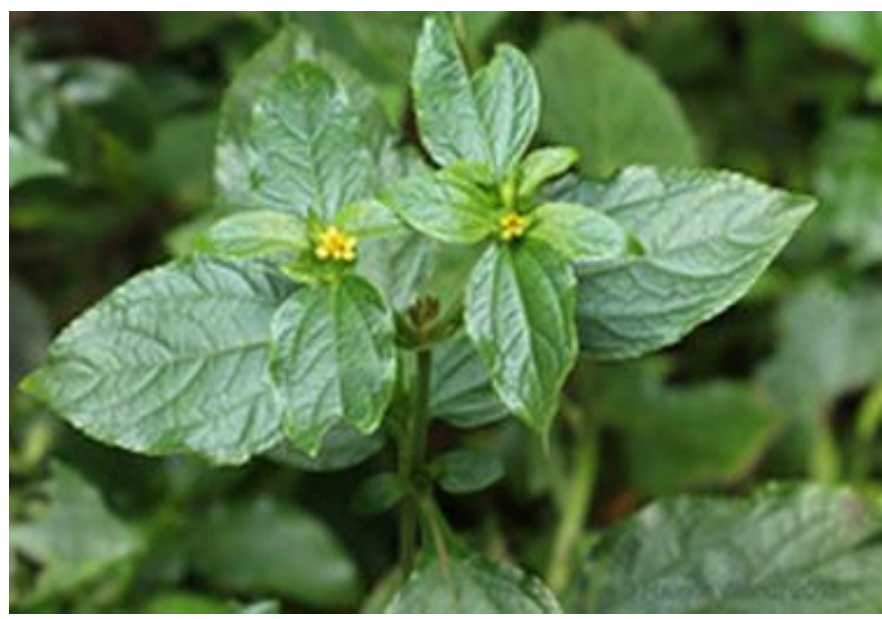

Figure 22 Synedrella nodiflora plant

The presence of various phytochemicals in the leaf extracts of Synedrella nodiflora was reported after screening in studies by Amoateng et al. [164]; Amoateng et al. [165]; Popoola et al. [166]. Solvent extracts of S. nodiflora have been 
shown to contain glycosides, flavonoids, alkaloids, saponins steroids, tannins, phytosterols, triterpenoids gums and reducing sugars [167-170]. The plant is useful for the treatment of various diseases while its leaves are eaten as a vegetable by some livestock and human [166]. A study shows it possess sex hormone activity [171]. The leaves can be used as Pregnant Mare Serum Gonadotrophin supplier in animal husbandry and to improve reproductive parameters in female animals [172]. A study by Popoola et al. [166] showed enzymes (tyrosinase and elastase) inhibiting activities of the plant and its antioxidant properties to support and validate its acclaimed ethnopharmacological applications.

\subsection{Melanthera scanden and Aspilia africana (Compositae)}

Melanthera scanden and Aspilia africana (Compositae) are medicinal plants considered to be of great biological importance. Aspilia africana (Compositae) is a semi-woody herb that grows up to 2 meters high and widely distributed across tropical Africa [173]. Melanthera scanden is a scrambling herb of waste thickets, commonly dispersed in the forested areas and extending widely across tropical Africa. Melanthera scanden has similar medicinal uses with Aspilia africana. They are known to provide forage for all stock in thicket edges around villages. With haemostatic preparations they are used on cuts and fresh wounds $[174,175]$. They are used to draw up exudations from open fresh sores and promote healing as well as curbing inflammation [176, 177]. Antimicrobial, antioxidant, anti-inflammatory, Antidiabietic, hypolipidemic and antiplasmodial activities of the plants have been reported in some studies [175, 178180]. Both plants contain essential phytochemicals; possess mild antityrosinase and antioxidant capacities that provide clues to further understand their applications in folk medicine.

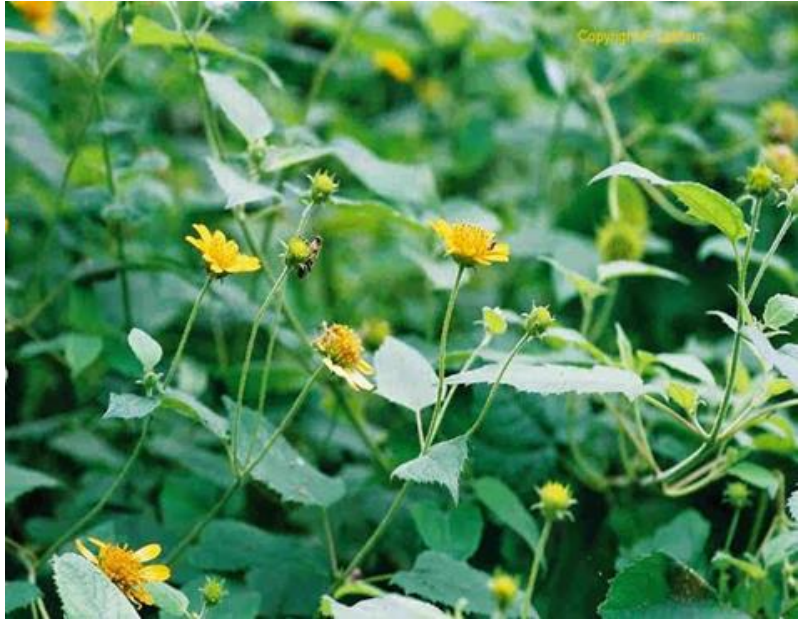

Figure 23 (a) Melanthera scanden

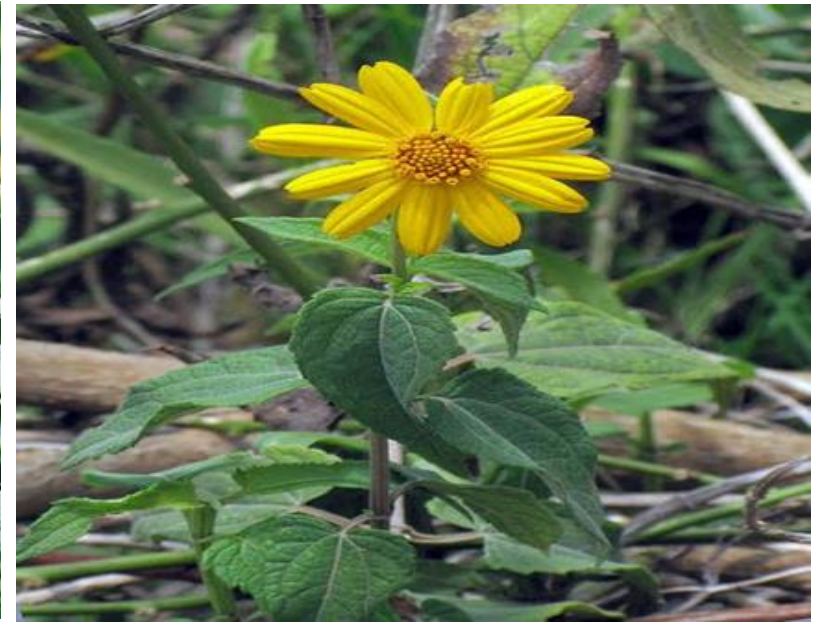

(b) Aspilia africana (Compositae)

\section{Conclusion}

The plants: Artemisia annua, Fraxinus excelsior, Sorghum bicolor, Ficus vallis-choudae, Zingiber officinale, Bouea macrophylla, Aspalathus linearis, Synedrella nodiflora, Phyllanthus niruri, Ficus vallis-choudae. Triclisia subcordata, Senna sulfurea, Withania coagulans, Melanthera scanden, Aspilia africana, Nauclea latifolia, Theobroma cacao, Centaurea austro-anatolica. Prosopis cineraria, Myrtus communis and Premna mucronata Roxb, are widely applied in traditional medicine. Extracts of these plants show a variety of biological therapeutic effects. The plants are cheap and effective source of alternative medicine to conventional synthetic drugs in treatments of diseases and disorders like ulcer, diarrhea, malaria, pyorrhea, anemia, joint pains, swelling of extremities, rheumatic pains, hypertension, skin diseases, cough, kidney, liver, asthma and urinary tract disorders as well as oxidative stress related diseases most especially in developing countries. The plants are rich sources of natural antioxidants. They invariably show antitumor, antinociceptive and antipyretic, antiinflammatory, Antimutagenic, antihyperglycemic, hepatoprotective, antimicrobials, antiplasmodial and larvicidal properties. The dosages and toxicological impacts of the plants on system functioning are not reported in this review and may become a subject of discussion in future reviews.

\section{Compliance with ethical standards}

\section{Acknowledgments}

The immense contribution of all the authors to the success of this review work is highly appreciated. 


\section{Disclosure of conflict of interest}

The authors declare that there are no conflicts of interests.

\section{References}

[1] Singh R. Medicinal Plants: A Review. Journal of Plant Sciences. Special Issue: Medicinal Plants. 2015; 3(1-1): 5055.

[2] Clark AM, Natural Products as a Source for New Drugs. Pharmaceutical Research. 1996; 13: 1133-1141.

[3] Olugbenga Kayode Popoola, Temidayo Oluwasegun Adedara, Adeola Taoreed Ajao, Mayowa Akinrinlola, Akinyemi Oluwafemi Olasanmi. Effect of Fermentation on the Factor of Skin Pigmentation Inhibitory Activity and Total Antioxidant Capacities Demonstrated by the South African Rooibos (Aspalathus linearis). Biomed J Sci \& Tech Res. 2019; 20(4): 15195-15202.

[4] Adekunle AA, Familoni OB, Okoli SO. Antifungal activity of bark extract of Ficus vallis-choudae and Detarium microcarpum. Acta SATECH. 2005; 2(2): 64-67.

[5] Aidi Wannes W, Marzouk B. Differences between myrtle fruit parts (Myrtus communis var. italica) in phenolics and antioxidant contents. J. Food Biochem. 2013; 37(5): 585-594.

[6] Mohammadhosseini M, Akbarzadeh A, HashemiMoghaddam H, Mohammadi Nafchi A, Mashayekhi HA, Aryanpour A. Chemical composition of the essential oils from the aerial parts of Artemisia sieberi by using conventional hydrodistillation and microwave assisted hydrodistillation: A comparative study. J. Essent. Oil-Bear. Plants. 2016; 19(1): 32-45.

[7] Fuentes L, Valdenegro M, Gómez MG, Ayala-Raso A, Quiroga E, Martínez, JP, Vinet R, Caballero E, Figueroa CR. Characterization of fruit development and potential health benefits of arrayan (Luma apiculata), a native berry of South America. Food Chem. 2016; 196: 1239-1247.

[8] Uche FI, Abed MN, Abdullah MI, Drijfhout FP, McCullagh J, Claridge TW, Richardson A, Li WW. Isochondodendrine and 2'-norcocsuline: additional alkaloids from Triclisia subcordata induce cytotoxicity and apoptosis in ovarian cancer cell lines. RSC Adv. 2017; 7(70): 44154-44161.

[9] Ahmed M, Khan MI, Khan MR, Muhammad N, Khan AU, Khan AR. Role of Medicinal Plants in Oxidative Stress and Cancer. OMICS Publishing Group. 2013; 2: 641.

[10] Akinwunmi OA, Adekeye DK, Olagboye SA. Phytochemical quantification, In vitro antioxidant and antidiabetic potentials methanol and dichloromethane extracts of Triclisia subcordata (Oliv) leaves. Trends in Phytochemical Research Journal. 2020; 4 (1): 17-24.

[11] Nageeb A, Al-Tawashi A, Emwas A-HM, Al-Talla ZA-H, Al-Rifai N. Comparison of Artemisia annua bioactivities between traditional medicine and chemical extracts. Curr. Bioact. Compd. 2013; 9: 324-332.

[12] Dama S, Abdoulaye AD, Ogobara KD. Methods for monitoring artemisinin-based combination therapies efficacy. Clin. Rev. Opinions. 2017; 8(1): 1-13.

[13] Steketee RW, Thomas PE. Watching the availability and use of rapid diagnostic tests (RDTs) and artemisininbased combination therapy (ACT). Malaria journal. 2017; 16(1): 165.

[14] Nekoei M, Mohammadhosseini M, Akhlaghi H. Chemical composition of the volatile oils from the aerial parts of Artemisia annua L. (Asteraceae) by using head space solidphase microextraction and hydrodistillation methods prior to gas chromatographic-mass spectrometric determination: A comparative investigation. J. Essent. Oil-Bear. Plants. 2012; 15(6): 926-933.

[15] Uche FI, Drijfhout FP, McCullagh J, Richardson A, Li WW. Cytotoxicity effects and apoptosis induction by bisbenzylisoquinoline alkaloids from Triclisia subcordata. Phytother. Res. 2016; 30(9): 1533-1539.

[16] Pasha Zanousi MB, Nekoei M, Mohammadhosseini M. Composition of the essential oils and volatile fractions of Artemisia absinthium by three different extraction methods: Hydrodistillation, solvent-free microwave extraction and headspace solid-phase microextraction combined with a novel QSRR evaluation. J. Essent. OilBear. Plants. 2016; 19(7): 1561-1581.

[17] Pasha Zanousi MB, Nekoei M, Mohammadhosseini M. Chemical compositions of the essential oils from stems, leaves and fruits of Artemisia tschernieviana and exploringquantitative structure-retention relationships (QSRRs) for prediction of corresponding retention indices. J. Essent. OilBear. Plants. 2017; 20(3): 672-687. 
[18] Evans WC. Trease and Evans Pharmacognosy, 14th Ed. Saunders, London. 1996.

[19] Vivien J, Faure JJ. Fruitiers sauvages d'AfriqueEspèces du Cameroun. Nguila-Kerou (Eds.), France. 1996 ; 416.

[20] Oliver B. Medicinal plants in Nigeria. Nigerian College of Arts and Science, Lagos, Nigeria. 1960.

[21] Lawan A, Katsayal UA, Yaro AH. Antiinflammatory and anti-nociceptive effects of the methanolic extract of the stem bark of Ficus vallis-choudae (Moraceae).Afr. J. Pharm. Pharmacol. 2008; 2(10): 200-203.

[22] Malami S, Kwanashie HO, Hussaini IM. Anticonvulsant effects of methanol extract of Ficus vallisChoudae (Moraceae) stem bark. Niger. J. Pharm. Sci. 2010; 9(1): 44-51.

[23] Awika JM, Rooney LW. Sorghum phytochemicals and their potential impact on human health. Phytochemistry. 2004; 65(9): 1199-1221.

[24] Oluwalana IB, Adedeji TO. Nutritional composition of a non-alcoholic beverage spiced with Zingiber officinale extract produced from Sorghum bicolorStem Sheath. Intern. J Food Sci. Nutr. Eng. 2013; 3(3): 21-27.

[25] Martínez-Pinilla E, Astibia AO, Franco R. The relevance of theobromine for the beneficial effects of cocoa consumption. Front Pharmacol. 2015; 6: 30.

[26] Abbe MMJ, Amin I. Polyphenols in cocoa and cocoa products: is there a link between antioxidant properties and health?. Molecules. 2008; 13(9): 2190-2219.

[27] Eubanks LP, Middlecamp CH, Pienta NJ, Heltzel CE, Weaver GC. Chemistry in Context: Applying Chemistry to Society. A Project of the American Chemical Society, 5th Ed, McGraw -Hill Companies Inc, New York, NY. 2006; 10020: 511.

[28] Wagenitz G. Centaurea L. In: Davis PH, Ed. Flora of Turkey and the East Aegean Islands, Vol. 5. Edinburgh University Press, Ediburgh. 1975; 493-494.

[29] Sarker SD, Savchenko T, Whiting P, Sik V, Dinan LN. Moschamine, cis-moschamine, moschamindole and moschamindolol: four novel indole alkaloids from Centaurea moschata. Nat. Prod. Lett. 1997; 9(3): 189-199.

[30] Baytop T. Therapy with Medicinal Plants in Turkey (Past and Present), Nobel Tip Kitabevi, Istanbul, Turkey. 1999.

[31] Ugur A, Sarac N, Ceylan O, Duru ME. Chemical composition of endemic Centaurea autro-anatolica and studies of its antimicrobial activity against multi-resistant bacteria. Acta Pharm. 2009; 59(4): 463-472.

[32] Kerr G. A review of black heart of ash (Fraxinus excelsior L). Forestry. 1998; 71(1): 49-56.

[33] Gaedcke F. Fraxinus. In: Hänsel R, Keller K, Rimpler H, Schneider G. editors. Hagers Handbuch der Pharmazeutischen Praxis. Drogen E-O, Springer-Verlag, Berlin. 1993; 5: 188-200.

[34] Bruneton J. Coumarins. In: Bruneton J. Pharmacognosy, Phytochemistry, Medicincal Plants. 2nd Edition. Lavoisier Publishing Inc., Paris. 1999; 263-267.

[35] Duke JA, Bogenschutz-Godwin MJ, du Cellier J, Duke PAK. European ash (Fraxinus excelsior L.) In: Duke JA, Bogenschutz-Godwin MJ, duCellier J, Duke PAK. Handbook of Medicinal Herbs. CRC Press, Boca Ranton, London, New York, Washington D.C. 2002; 280.

[36] Gruenwald J, Brendler T, Jaenicke C. Ash, Faxinus excelsior. In: Gruenwald, J., Brendler, T., Jaenicke, C., Editors. PDR for herbal medicines. Thomson. 2007; 53-54.

[37] Kostova I, Iossifova T. Chemical components of Fraxinus species. Fitoterapia. 2007; 78: 85-106.

[38] Tahirović A, Bašić N. Determination of phenolic content and antioxidant capacity of Fraxinus excelsior L. and Fraxinus angustifolia Vahl. leaves and bark extracts. Rad. Šumar. fak. Univ. Sarajevu. 2016; 46(1): 29-41.

[39] Carnat A, Lamaison JL, Duband F. Teneurs en principaux constituants de la feuille de frêne, Fraxinus excelsior L. Plantes Méd Phytotér. 1990; 24: 145-151.

[40] Damtoft S, Franzyk H, Jensen SR. Excelsioside, a secoiridoid glucoside from Fraxinus excelsior. Phytochemistry. 1992; 31: 4197-4201.

[41] Quattrocchi U. CRC World Dictionary of Medicinal and Poisonous Plants: Common Names, Scientific Names, Eponyms, Synonyms, and Etymology. CRC Press, Boca Raton, Florida. 2012; 3417.

[42] Kiritikar KR, Basu BD. Indian Medicinal Plants, Periodical experts, New Delhi. 2012; 910-911. 
[43] Kirtikar KR, Basu BD, Eds. Indian Medicinal Plants. Vol. III, Bishen Singh and Mahendra Pal Singh, Dehradun, Allahabad. 1984; 1664-1666.

[44] Nadkarni KM. Indian Materia Medica, Vol. 1, Popular Prakashan, Mumbai, India. 2000; 290: 1011-1014.

[45] Janbaz KH, Haider S, Imran I, Zia-Ul-Haq M, Martino LD, Feo VD. 2012. Pharmacological Evaluation of Prosopis cineraria (L.) Druce in gastrointestinal, respiratory, and vascular disorders. Evidence-Based Complem. Altern. Med. 2012.

[46] Ghazanfar SA, Alsabahi AMA. Medicinal plants of northern and central Oman (Arabia). Econ Bot. 1993; 47(1): 8998.

[47] Rajan NS, Bhat R. Antioxidant compounds and antioxidant activities in unripe and ripe Kundang fruits (Bouea macrophylla Griffith). Fruits. 2016; 71(1): 41-47.

[48] Rajan NS, Bhat R. Volatile constituents of unripe and ripe Kundang fruits (Bouea macrophylla Griffith). Int. J. Food Prop. 2017; 20(8): 1751-1760.

[49] Rajan NS, Bhat R, Karim AA. Preliminary studies on the evaluation of nutritional composition of unripe and ripe 'Kundang' fruits (Bouea macrophylla Griffith). Int. Food Res. J. 2014; 21(3): 985-990.

[50] Ikram EHK, Eng KH, Jalil AMM, Ismail A, Idris S, Azlan A, Nazri HSM, Diton NAM, Mokhtar RAM. Antioxidant capacity and total phenolic content of Malaysian underutilized fruits. J. Food Comp. Analys. 2009; 22(5): 388393.

[51] Sukalingam K. Preliminary phytochemical analysis and In vitro antioxidant properties of Malaysian 'Kundang' (Bouea macrophylla Griffith) Trends in Phytochemical Research. 2018; 2(4): 261-266.

[52] Agrimonti C, Bianchi R, Bianchi A, Ballero M, Poli F, Marmiroli N. Understanding biological conservation strategies: A molecular-genetic approach to the case of myrtle (Myrtus communis L.) in two Italian Regions: Sardinia and Calabria. Conserv. Genet. 2007; 8(2): 385-396.

[53] W Aidi Wannes, M Saidani Tounsi, B Marzouk. Morphological and chemical characterization of two wild Tunisian myrtle (Myrtus communis L.) populations Trends Phytochem. Res. 2019; 3(4): 231-242.

[54] Mulas M. The myrtle (Myrtus communis L.) case, from a wild shrub to a new fruit crop. Acta Horticult. 2012; 948(27): 235-242.

[55] Barboni T, Venturini N, Paolini J, Desjobert JM, Chiaramonti N, Costa J. Characterisation of volatiles and polyphenols for quality assessment of alcoholic beverages prepared from Corsican Myrtus communis berries. Food Chem. 2010; 122(4): 1304-1312.

[56] Sanna D, Mulas M, Molinu MG, Fadda A. Oxidative stability of plant hydroalcoholic extracts assessed by EPR spin trapping under forced ageing conditions: A myrtle case study. Food Chem. 2019; 271: 753-761.

[57] Aidi Wannes W, Marzouk B. Maturational effect on essential oil yield and composition of Myrtus communis var. baetica fruit. J. Essent. Oil bear. Pl. 2012; 15(5): 847-853.

[58] Usai M, Marchetti M, Mulas M. Chemical composition of essential oils of leaves and flowers from five cultivars of myrtle (Myrtus communis L.). J. Essent.Oil Res. 2015; 27(6): 465-476.

[59] Scazzocchio F, Garzoli S, Conti C, Leone C, Renaioli C, Pepi F, Angiolella L. Properties and limits of some essential oils: chemical characterisation, antimicrobial activity, interaction with antibiotics and cytotoxicity. Nat. Prod. Res. 2016; 30(17): 1909-1918.

[60] Anwar S, Crouch RA, Awadh Ali NA, Al-Fatimi MA, Setzer WN, Wessjohann L. Hierarchical cluster analysis and chemical characterisation of Myrtus communis L. essential oil from Yemen region and its antimicrobial, antioxidant and anti-colorectal adenocarcinoma properties. Nat. Prod. Res. 2017; 31(18): 2158-2163.

[61] Tardugno R, Pellati F, Iseppi R, Bondi M, Bruzzesi G, Benvenuti S. Phytochemical composition and In vitro screening of the antimicrobial activity of essential oils on oral pathogenic bacteria. Nat. Prod. Res. 2018; 32(5).

[62] Usai M, Marchetti M, Culeddu N, Mulas M. Chemical composition of myrtle (Myrtus communis L.) berries essential oils as observed in a collection of genotypes. Molecules. 2018; 23: 1-20.

[63] Tuberoso CIG, Melis M, Angioni A, Pala M, Cabras P. Myrtle hydroalcoholic extracts obtained from different selections of Myrtus communis L. Food Chem. 2007; 101(2): 806-811. 
[64] Panjeshahin MR, Azadbakht M, Akbari N. Atidiabetic activity of different extracts of Myrtus communis in streptozotocin induced diabetic rats. Rom. J. Diabetes Nutr. Metab. Dis. 2016; 23(2): 183-190.

[65] Khan N, Rasool S, Ali Khan S, Bahadar Khan S. A new antibacterial dibenzofuran-type phloroglucinol from Myrtus communis linn, Nat. Prod. Res. 2019.

[66] Talebianpoor MS, Mansourian M, Vafaiee-Nejad T. Antidiabetic activity of hydroalcoholic extract of Myrtus communis (myrtle) fruits in streptozotocin-induced and dexamethasoneinduced diabetic rats. Pharmacognosy Res. 2019; 11(2): 115-120.

[67] Diksha Palariya, Anmol Singh, Anamika Dhami, Ravendra Kumar, Anil K. Pant and Om Prakash. Phytochemical analysis and screening of antioxidant, antibacterial and antiinflammatory activity of essential oil of Premna mucronata Roxb. leaves Trends Phytochem. Res. 2019; 3(4): 275-286.

[68] Suresh G, Babu KS, Rao VRS, Rao MSA, Nayak VL, Ramakrishna S. Novel cytotoxic icetexane diterpenes from Premna latifolia Roxb. Tetrahedron Lett. 2011; 52(12): 1273-1276.

[69] Rekha K, Richa PK, Babu S, Rao M. A phytochemistry of the genus Premna: a review. Int. J. Chem. Pharm. Sci. 2015; 4(3): 317-25.

[70] Savasani H, Shah H, Patel K, Gandhi T. Cardioprotective effect of flavonoids rich fraction of Premna mucronata on isoproterenolinduced myocardial infarction in wistar rats. Int. J. Phytopharmacol. 2014; 5(2): 95-108.

[71] Renjana PK, John ET. Larvicidal activities of the leaf extracts and essential oil of Premna latifolia Roxb. (Verbenaceae) against Aedes albopictus Skuse (Diptera: Culicidae). J.App. Pharm. Sci. 2013; 3(06): 101-105.

[72] Patel NG, Patel KG, Patel KV, Gandhi TR. 2015. Myocardial salvaging effect of Premna mucronata Roxb. (Verbenaceae) on isoproterenol induced myocardial necrosis in rats. Der Pharm. Lett. 2015; 7(7): $137-147$.

[73] Dianita R, Jantan I. Ethnomedicinal uses, phytochemistry and pharmacological aspects of the genus Premna: a review. Pharm. Biol. 2017; 55(1): 1715-1739.

[74] Jena AK, Karan M, Vasisht K. Plant parts substitution based approach as a viable conservation strategy for medicinal plants: A case study of Premna latifolia Roxb. J-AIM. 2017; 8: 68-72.

[75] de Lima JPS, Pinheiro MLB, Santos AMG, Pereira JLS, Santos DMF, Barison A, Silva-Jardim I, Costa EV. In vitro antileishmanial and cytotoxic activities of Annona mucosa (Annonaceae). Rev. Virt. Quim. 2012; 4: 692-702.

[76] Ribeiro LP, Vendramim JD, Gonçalves GLP, Ansante TF, Gloria EM, Lopes JC, Mello-Silva R, Fernandes JB. Searching for promising sources of grain protectors in extracts from Neotropical Annonaceae. Bol. Latino. Amer. Caribe. Plantas. Medicinales. Aromát. 2016; 15: 215-232.

[77] Ribeiro LP, Vendramim JD, Bicalho KU, Andrade MS, Fernandes JB, Moral RA, Demétrio CGB. Annona mucosa Jacq. (Annonaceae): A promising source of bioactive compounds against Sitophilus zeamais Mots. (Coleoptera: Curculionidae). J. Stored.Prod. Res. 2013; 55: 6-14.

[78] Moghadamtousi SZ, Fadaeinasab M, Nikzad S, Mohan G, Ali HM, Kadir HA. Annona muricata (Annonaceae): A review of its traditional uses, isolated acetogenins and biological activities. Int. J. Mol. Sci. 16: 15625-15658.

[79] Ferreira MGR, Santos MRA, Silva EO, Gonçalves EP, Alves EU, Bruno RLA. Emergência e crescimento inicial de plântulas de biribá (Rollinia mucosa (Jacq.) Baill) (Annonaceae) em diferentes substrates. Semin. Ciênc. Agrár. $2010 ; 31: 373-380$.

[80] Morton J. Biriba. In: Fruits of Warm Climates. Morton JF, Miami FL. 1987; 88-90.

[81] Pathak K, Zaman K. An overview on medicinally important plant-Annona reticulata Linn. Int. J. Pharm. Pharm. Res. 2013; 5: 299-30.

[82] Akanksha G, Garud N, Tailang M. Annona squamosa: A review on its larvicidal, oviposition deterrent and insect repellent potency. World J. Pharm. Res. 2015; 4: 452-463.

[83] Nawwar M, Ayoub N, Hussein S, Hashim A, El-Sharawy R, Wende K, Harms M, Lindequis U. Flavonol triglycoside and investigation of the antioxidant and cell stimulating activities of Annona muricata linn. Arch. Pharmacol. Res. 2012; 35: 761-767.

[84] Adebayo EA, Ishola OR, Taiwo OS, Majolagbe ON, Adekeye BT. Evaluation of the methanol extract of Ficus exasperata stem bark, leaves and roots for phytochemical analysis and antimicrobial activities. Afr. J. Plant Sci. 2009; 3(12): 283-287. 
[85] Sirisha N, Sreenivasulu M, Sangeeta K, Madhusudhana CC. Antioxydant properties of Ficus species - A review. Int. J. PharmTech Res. 2010; 2(4): 2174-2182.

[86] Ohunayo A, Adekeye D, Dauda O, Odeniyi I, Popoola O, Akinwunmi O. Microbial Profile of the Phyllosphere and the Antimicrobial Potency of Ficus vogelii Extracts. Journal of Pharmaceutical Sciences and Research. 2020; 12(1): 191-195.

[87] Berg CC, Wiebes JT. African Fig Trees and Fig Wasps. Koninklijke Nederlandse Akademie van Wetenschappen, Amsterdam. 1992; 1-298.

[88] Ijeh II, Ukweni AIJ.Acute effect of administration of ethanol extracts of Ficus exasperata vahl on kidney function in albino rats. J. Med. Plants Res. 2007; 1: 27-29.

[89] Amponsah IK, Fleischer TC, Dickson RA, Annan K, Thoss V. Evaluation of antiinflammatory and antioxidant activity of Furanocoumarins and Sterolin from the stem bark of Ficus exasperata Vahl. (Moraceae). J. Sci. Innov. Res. 2013; 2(5): 880-887.

[90] Mouho DG, Oliveira AP, Kodjo CG, Valentão P, Gillzquierdo A, Andrade PB, Ouattara ZA, Bekro YA, Ferreres F. Chemical findings andIn vitrobiological studies to uphold the use of Ficus exasperata Vahl leaf and stem bark. Food Chem. Toxicol. 2018; 112: 134-144.

[91] Noumi E, Yomi A. Medicinal plants used for intestinal diseases in Mbalmayo Region, Central Province, Cameroon. Fitoterapia. 2001; 72: 246-254.

[92] Titanji VP, Zofou D, Ngemenya MN. The antimalarial potential of medicinal plants used for the treatment of malaria in Cameroonian folk medicine. Afr.J. Tradit. Complement. Altern. Med. 2008; 5: 302-321.

[93] Focho DA, Ndam WT, Fonge BA. Medicinal plants of Aguambu-Bamumbu in the Lebialem highlands, southwest province of Cameroon. Afr. J. Pharm. Pharmacol. 2009; 3: 1-13.

[94] Nnamonu LA, Tor-Anyiin TA, Ugbenyo NO, Anyam JV. Isolation and characterization of $\alpha$-amyrin from stem bark of Ficus exasperata (Vahl). Biotechnol.J. Int. 2016; 16(4): 1-7.

[95] Odunbaku OA, Ilusanya OA, Akasoro KS. Antibacterial activity of ethanolic leaf extract of Ficus exasperata on Escherichia coli and Staphylococcus albus. Sci. Res. Essays. 2008; 3(11): 562-564.

[96] Woode E, Poku RA, Ainooson GK, Boakye-Gyasi E, Abotsi WKM, Mensah TL. An evaluation of the antiinflammatory, antipyretic and antinociceptive effects of Ficus exasperata (Vahl) leaf extract. J. Pharmacol. Toxicol. 2009; 4(4): 135-151.

[97] Trease G, Evans SM. Medicinal plants and Traditional medicines in Africa, 2nd edition, spectrum books. 1993; 3553.

[98] Kumeshini SU. Preliminary phytochemical analysis and In vitro antioxidant properties of Malaysian 'Kundang' (Bouea macrophylla Griffith). Trends Phytochem. Res. 2018; 2(4): 261-266.

[99] Dalziel JK. The useful plants of West Tropical Africa., 2nd ed. Crown Agents, London. $1957 ; 361$.

[100] Irvine FR. Woody plants of Ghana, Oxford University Press, London. 1961.

[101] Asuzu IU, Anaga AO. The anti-ulcer effect of methanolic extract of Triclisia subcordata 0. leaves in rats. J. Herbs Spices Med. Plants. 1995; 3(3): 45-53.

[102] Abo KA, Lawal IO, Ogunkanmi A. Evaluation of extracts of Triclisia suboardata Oliv and Heinsia crinita (Afz) G. Taylor for antimicrobial activity against some clinical bacterial isolates and fungi. Afr. J. Pharm. Pharmacol. 2011; 5(2): 125-131.

[103] Ayoola MD, Akinwunmi KF, Agboola OB. Antidiabetic and antioxidant activities of Entandrophragma cylindricum and Triclisia subcordata. Niger J. Nat. Prod.Med. 2017; 21(1): 24-31.

[104] Lötter D, Maitre D. Modelling the distribution of Aspalathus linearis (Rooibos tea): Implications of climate change for livelihoods dependent on both cultivation and harvesting from the wild. Ecology and Evolution. 2014; 4(8): 1209-1221.

[105] Joubert E, De Villiers OT. Effect of fermentation and drying conditions on the quality of rooibos tea. IJFS International Journal of Food Science and Technology. 1997; 32(2): 127-134.

[106] Joubert E, Gelderblom WC, Louw A, De Beer D. South African herbal teas: Aspalathus linearis, Cyclopia spp. and Athrixia phylicoides - a review. Journal of Ethnopharmacology. 2008; 119(3): 376-412. 
[107] Huang M, Du Plessis J, Du Preez J, Hamman J, Viljoen A. Transport of aspalathin, a Rooibos tea flavonoid, across the skin and intestinal epithelium. Phytotherapy Research. 2008; 22(5): 699-704.

[108] Street RA, Prinsloo G. Commercially important medicinal plants of South Africa: A review. Journal of Chemistr. 2013.

[109] Mckay DL, Blumberg JB. A review of the bioactivity of South African herbal teas: rooibos (Aspalathus linearis) ands honeybush (Cyclopia intermedia). Phytotherapy Research. 2007; 21(1): 1-16.

[110] Krafczyk N, Glomb MA. Characterization of phenolic compounds in rooibos tea. Journal of Agriculture and Food Chemistry. 2008; 56(9): 3368- 3376.

[111] Gidado A, Ameh DA, Atawodi SE. Effect of Nauclea latifolia leaves aqueous extracts on blood glucose levels of normal and alloxan-induced diabetic rats. African Journal of Biotechnology. 2005; 4(1): 91-93.

[112] Deeni Y, Hussain H. Screening for antimicrobial activity and for alkaloids of Nauclea latifolia. Journal Ethnopharmacology. 1991; 35: 91 - 96.

[113] Akubue P, Mittal GC. Clinical evaluation of a traditional herbal practice in Nigeria: A preliminary Report. Journal of Ethnopharmacology. 1982; 6(3): 355 - 359.

[114] Abbah J, Amos S, Chindo B, Ngazali I, Vongtau HO, Adzu B, Farida T, Oduntola AA, Wambebe C, Gamaniel KS. Pharmacological evidence favouring the use of Nauclea latifolia in malaria ethnopharmacy: Effects against nociception, inflammation, and pyrexia in rats and mice. Journal of Ethnopharmacology. 2010; 127(1): 85-90.

[115] Elujoba AA. Female infertility in the hands of traditional birth attendants in South-West Nigeria. Fitoterapia. $1995 ; 66(3): 239-248$.

[116] Traore FM, Gasquet M, Laget H, Guirand Di-Giorgio C. Toxicity and genotoxicity of antimalarial alkaloidrich extracts Derived from Mytragy na inermis O.kuntze and Nauclea latifolia. Phytotherapy Research. 2000; 14: 60861.

[117] Gidado AA, Ameh D, E Atawodi S, Ibrahim S. Antidiabetic Effect of Nauclea latifolia Leaf Ethanolic Extract in Streptozotocin-induced diabetic rats. Pharmacognosy Research. 2009; 1(6): 392-395.

[118] Yenesew A, Derese S, Midiwo JO, Irungu B, Waters NC, Liyala P, Akala H, Heydenreich M, Peter MG. Flavonoids and isoflavonoids with antiplasmodial activities from the root bark of Erythrina abyssinica. Planta Med. 2003; 69(7): 658-661.

[119] Abbiw DK. Useful plants of Ghana, Intermediate Technology Publications and the Royal Botanic Gardens Kew, London. 1990; 154-157.

[120] Adebowale EA. Some ethno veterinary and traditional management practices in livestock production. In proceeding of a workshop on indigenous knowledge in agriculture and development, Ibadan, Nigeria. 1993. 2426.

[121] Ademola IO, Fagbemi BO, Idowu SO. Antihelminthic efficacy of Nauclea latifolia Extract against gastrointestinal nematodes of sheep In vitro and in vivo studies. African Journal of Traditional, Complementary and Alternative Medicine. 2007; 4(2): 148-156.

[122] Abdullahi M, Amupitan JO, Oyawale A0, Okogun JI, Ibrahim K. 2007. An ethnobotanical survey of indigenous flora for treating tuberculosis and other respiratory diseases in Niger State, Nigeria. Journal of Phytomedicine and Therapeutics. 2007; 12: 1-12.

[123] Seif G, Solafa A, Awadalla A, Isam A. Yield and quality attributes of faba bean inbred lines grown under marginal environmental conditions of Sudan. Food Sci. Nutr. 2015; 3(6): 539-547.

[124] Rocha V, Ras R, Gagliardi A, Mangili L, Trautwein E, Santos R. Effects of phytosterols on markers of inflammation: A systematic review and meta-analysis.Atherosclerosis. 2016; 248: 76-83.

[125] Bouchenak M, Lamri-Senhadji M. Nutritional quality of legumes, and their role in cardiometabolic risk prevention: a review. J. Med. Food. 2013; 16(3): 1-14.

[126] Piotr G, Cristina M, Małgorzata K, Juana F. Non-nutritive compounds in Fabaceae family seeds and the improvement of their nutritional quality by traditional processing - a review. Pol. J. Food Nutr. Sci. 2014; 64(2): 75-89.

[127] Boukhanouf S, Louaileche H, Perrin D. Phytochemical content and In vitro antioxidant activity of faba bean ( $V$. faba L.) as affected by maturity stage and cooking practice. Int. Food Res. J. 2016; 23(3): 954-961. 
[128] Lavin M, Pennigton RT. Delimitation of a pantropic legumes. J. Bot. Sci. 2001; 8: 503-511.

[129] Assanta MA, Robert C. Gnetum africanum, a wild food plant from the African forest with many nutritional and medicinal purposes. Afr. J. Herb. Med. 2011; 14: 1289-1297.

[130] Dike MC. Proximate and nutrient composition of some fruits, seeds and leaves of some plant species at Umudike, Nigeria. ARPN J. Agric. Biol. Sci. 2010; 5: 7-16.

[131] Oteng-Gang K, Mbachu JI. Changes in the ascorbic acid content of some tropical leafy vegetables during traditional cooking and local processing. Food Chem. 1990; 23: 9-17.

[132] Bremaud I, Amusant N, Minato K, Gril J, Thibaut B. Effect of extractives on vibrational properties of African Padauk (Pterocarpus soyauxii Taub). Wood Sci.Tech. 2011; 45: 461-472.

[133] Arnone A, Camarda L, Merlini L, Nasini G, Taylor DAH. Coloring matters of the West African red woods Pterocarpus osun and P. soyauxii. Structures of santarubins A and B. J. Chem. Soc. Perkin Trans. 1977; 1(19): 2116-2118.

[134] Barend CB, Brandt BEV. Flavonoid analogs from Pterocarpus species. Phytochemistry. 1987; 26: 531-535.

[135] Saha JBT, Abia D, Dumarcay S, Ndikontar MK, Gerardin P, Ngamveng NJ, Perrin D. Antioxidant activities, total phenolic contents and chemical compositions of extracts from four Cameroonian woods: Padouk (Pterocarpus soyauxii Taub), tali (Erythrophleum suaveolens), moabi (Baillonella toxisperma), and movingui (Distemonanthus benthamianus). Ind. Crop Prod. 2013; 41: 71-77.

[136] Oteng-Gyang, K, Mbachu JI. Changes in the ascorbic acid content of some tropical leafy vegetables during traditional cooking and local processing. Food Chem. 1987; 23: 9-17.

[137] Tchamadeu MC, Dzeufiet PD, Nana P, Kouambou NC, Ngueguim TF, Allard J, Blaes N, Siagat R, Zapfack L, Girolami, JP, Tack I, Kamtchouing P, Dimo T. Acute and sub-chronic oral toxicity studies of an aqueous stem bark extract of Pterocarpus soyauxii Taub (Papilionaceae) in rodents. J. Ethnopharmacol. 2011; 133: 329 -335.

[138] Showkat Rassol Mir, Mohammed Ali , Mohammad Waris and Shahnaz Sultana Chemical constituents from the fruits of Withania coagulans (Stocks) Dunal Trends Phytochem. Res. 2020; 4(2): 45-58.

[139] Kirtikar KR, Basu BD. Indian Medicinal Plants with Illustrations. International Book Distributors. 1999; 3: 17741777.

[140] Dymock W, Waden CJH, Hopper D. Pharmacographia Indica, Institute of health and TB Research, Karachi. 1972; 306.

[141] Bown D. Encyclopedia of Herbs and their Uses. Dorling Kindersley, London. 1995; 500.

[142] Khodaei M, Jafari M, Noori M. Remedial use of withanolides from Withania coagolans (Stocks) Dunal. Advances in Life Sci. 2012; 2(1): 6-19.

[143] Nadkarni KM. Indian Materia Medica, Revised and enlarged by Nadkarni A.K., Popular Prakashan Pvt. Ltd. Bombay. 2002; 34(1): 12-91.

[144] Maurya R, Akanksha J. Chemistry and pharmacology of Withania coagulans: An Ayurvedic remedy. J. Pharm. Pharmacol. 2010; 62: 153-160.

[145] Mathur D, Agrawal RC. Evaluation of in vivo antimutagenic potential of fruits extracts of Withania coagulans. Der Pharma Chem. 2011; 3(4): 373-376.

[146] Haq I, Youn UJ, Chai X, Park EJ, Kondratyuk TP, Simmons CJ, Borris RP, Mirza B, Pezzuto JM, Chang LC. Biologically active withanolides from Withania coagulans. J. Nat. Prod. 2013; 76(1): 22-28.

[147] Mathur D, Agrawal RC, Shrivastava V. Phytochemical screening and determination of antioxidant potential of fruits extracts of Withania coagulans. Recent Res. Sci. Techn. 2011; 3(11): 26-29.

[148] Hung NV, Huong LT, Dai DN, Sam LN, Thanh NT. New record of Zingiber nitens M.F. Newman for flora in Vietnam. VNU J. Nat. Sci. Technol. 2017; 33(1): 46-50.

[149] Huong LT, Huong TT, Huong NTT, Hung NH, Dat PTT, Luong NX, Ogunwande IA. Chemical composition and larvicidal activity of essential oils from Zingiber montanum against three mosquito vectors. Bol. Latinoam. Caribe Plantas Med. Aromat, In press. 2020.

[150] Hung NV, Dai DN, Thai TH, San ND, Ogunwande IA. Zingiber nitens M.F. Newman: A new species and its essential oil constituent. J. Essent. Oil Bearing Plants. 2017; 20(1): 69-75 
[151] Azelan, N.A., Rosnani, H., Awang, M.A., Abd Malek, R., Musa, N.F., Ramlan, A., 2015. Antibacterial activity of Zingiber ofcinale and Zingiber zerumbet essential oils extracted by using turbo extractor distillatory. UTNM J. Technol. 77(1), 43-47

[152] Huong LT, Huong TT, Huong NTT, Hung NH, Dat PTT, Luong NX, Ogunwande IA. Mosquito larvicidal activities of the essential oil of Zingiber collinsii against Aedes albopictus and Culex quinquefasciatus. J. Oleo Sci. 2020; 69(2): 153-160.

[153] Jeevani Maheshika Dahanayake, Pathirage Kamal Perera, Priyadarshani Galappaththy, Menuka Arawwawala. A mini-review on therapeutic potentials of Phyllanthus niruri Linn. Trends Phytochem. Res. 2020; 4(3): $101-108$.

[154] Lee NYS, Khooa WKS, Adnana MA, Mahalingam TP, Fernandez AR, Jeevaratnam K. The pharmacological potential of Phyllanthus niruri. J. Pharm.Pharmacol. 2016; 68: 953-969.

[155] Sharma PV. Dravyaguna Vignana, Vol. II, Chaukhambha Bharati academy, Varanasi, India. 1998.

[156] Harish R, Shivanandappa T. Antioxidant activity and hepatoprotective potential of Phyllanthus niruri. Food Chem. 2006; 95: 180-185.

[157] Narendra K, Swathi J, Sowjanya KM, Satya AK. Phyllanthus niruri: A review on its ethno botanical, phytochemical and pharmacological profle. J. Pharma. Res. 2012; 5(9): 4681-4691.

[158] Giribabu Rao PV, Kumar KP, Muniandy S, Rekha SS, Salleh N. Aqueous extract of Phyllanthus niruri leaves displays In vitro antioxidant activity and prevents the elevation of oxidative stress in the kidney of Streptozotocin-induced diabetic male rats. Evid-Based Complement. Altern. Med. 2014.

[159] Manonmani P, Ramar M, Geetha N, Arasu ME, Raskin E, Sowmiya JJ. Hepatoprotective activity of aqueous extract of Phyllanthus niruri in CCl4 induced liver toxicity-in vivo study. Res. J. Biotechnol. 2015; 10(9): 11-17.

[160] Jantan I, Haque A, Ilangkovan M, Arshad L. An insight into the modulatory effects and mechanisms of actions of Phyllanthus species and their bioactive metabolites on the immune system. Front. Pharmacol. 2019; 10(878).

[161] Penjin B, Ciric A, Markovic JD, Glamoclija J, Nikolic M, Stanimirovic B, Sokovic M. Quercetin potently reduces bioflm formation of the strain Pseudomonas aeruginosa PA01 In vitro. Curr. Pharm. Biotech. 2015; 16(8).

[162] USDA National Plant Data Center, Asteraceae of North America Update, database(version 2010.5.13). Update coordinated by the International Compositae Alliance (TICA).

[163] Amoateng P, Koffuor GA, Sarpong K, Agyapong KO. Free radical scavenging and anti-lipid peroxidative effects of a hydro-ethanolic extract of the whole plant of Synedrella nodiflora (L.) Gaertn (Asteraceae). Free Rad Antiox. 2011; $1: 70-8$.

[164] Amoateng P, Woode E, Kombian SB. Anticonvulsant and related neuropharmacological effects of the whole plant extract of Synedrella nodiflora (L.) Gaertn(Asteraceae). J Pharm Bioall Sci. 2012; 4: 140-8.

[165] Popoola et al. Phytotherapeutic Potentials of Synedvilla Nodiflora: In-vitro Quantification of Phytochemical Constituents, Antioxidant Capacities and Skin Enzymes Inhibiting Activities. American Journal of Biomedical Science \& Research 2020; 10(6): 543-550.

[166] Rathi MJ, Gopalkrishnan S. Insecticidal activity of aerial parts of Synedrella nodiflora (L.) Gartn (Compositae) on Sapodeptera latura (FAB). J.cent.Eur.Agric. 2005; 6: 323-328.

[167] Woode E, Amoateng P, Abotsi WM. Ethopharmacological analysis of the effects of the whole plant extract of Synedrella nodiflora (L.) Gaertn (Asteraceae) in murine models. Der Pharmacia Sinica. 2011; 2: 54-67.

[168] Hossain S, Mallik J. Phytochemical screening and In vitro evaluation of reducing power of ethanol extracts of Synedrella nodiflora. IJRRPAS. 2012; 2(5): 879-890.

[169] Hidayat S. Synedrella nodiflora (L.) Gaertner[Internet] Record from Proseabase. Van Valkenburg, JLCH. and Bunyapraphatsara, N. (Editors). PROSEA (Plant Resources of South-East Asia) Foundation, Bogor, Indonesia. 2014.

[170] Mannan A. Ahmad K. Preliminary study of sex hormones of medical importance inBangladeshi plants. Bangladesh Med Res Counc Bull. 1978; 4(2): 78-85.

[171] Koutinhouin GB, Kpodekon TM, Tougan UP, Hanzen CH, Zonatchia GG, Assogba MC, Thewis A. Comparative survey of Synedrella nodiflora (L.) Gaertn leaves and commercial Pregnant Mare Serum Gonadotrophin (Gonaser $®$ ) on reproductive performance in rabbits does. Tropical Animal Health and Production. 2015. 
[172] Dalziel JM. The useful Plants of West African. Crown Agents. London. 1973.

[173] Okoli CO, Akah PA, Okoli AS. Potentials of leaves of Aspilia africana (Compositae) in wound care: An experimental evaluation. BMC Complementary and Alternative Medicine. 2007; 7: 24.

[174] Jude EO, Anwanga EU, Samuel GF, Louis U, Amazu. Anti-inflammatory and analgesic activities of Melanthera scandens Article in Asian Pacific Journal of Tropical Biomedicine 2012: 144-148.

[175] Dimo T, Tan PV, Dongo E, Kaintchouing P, Raktoniria SV. In vitro Vascular Smooth Muscle Contractile Activity of Aspilia africana Extract on Rat Aortic Preparation. Pharmazie. 2002; 57(6): 421-3.

[176] Agyare C, Asase A, Lechtenberg M, Niehues M, Deters A, Hensi A. An ethnopharmacological survey and In vitro confirmation of ethnopharmacological use of medicinal plants used for wound healing in Gosomtwi-AtwimaKwanwoma area, Ghana. J Ethnopharmacol. 2009; 125: 393-403.

[177] Adeniyi BA, Odufowora RO. In-vitro Anti-microbial Properties of Aspilia africana. African J. of Biomedical Research. 2000; 3(3): 167-70.

[178] Guede ZN, Mambu L, Guede-Guina F, Bodo B, Grellier P. In vitro antiplasmodial activity and cytotoxicity of 33 West African plants used for treatment of malaria. J Ethnopharmacol. 2005; 98: 281-285.

[179] Adeseguna SA, Alabia SA, Olabanja PA, Alexander H, Coker B. Evaluation of antioxidant potential of Melanthera scandens. J. Acupunct Meridian Stud. 2010; 3(4): 267-271.

[180] Offong E. Antidiabetic and hypolipidemic activities of Melanthera scadens (M.Sc. dissertation). University of Uyo, Uyo, Nigeria. 2011. 